د. عبد المجيا بن صالح المنصور عـ

أثز فكر الإلحاد

على أمن الضروريات الخمس

د. ـبد المجيد بن صالح المنصور (")

المقدمة :

الحمد الله الذي أرشد عقول أوليائه إلى توحيده وهداها، وثتَّت كلمة الإخلاص

في قلوبٍ أحبابه على أمواج الامتحان بسم الله مجريها ومرساها، وأعمى بصائر

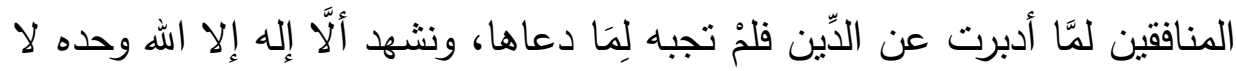

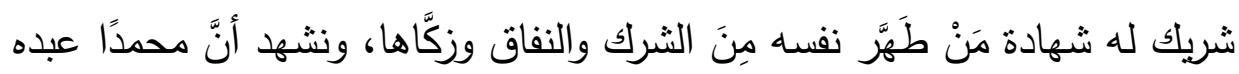
ورسوله المبعوث بأكمل الثرائع وأسنَْاها، صلى الله عليه وعلى آله وأصحابه الذين عضوا على سنته بالنواجذ وتمسكوا بعراها، وسلم تسليمًا: أمَّا بعد:

فإن الله تعالى الملك العادل، قَّرَ الصراع بين الحق والباطل، وجعل للحقِ أنصارًا وأتباعًا، وللباطل فِرقًا وأثنياعًا؛ لتتم سُنَّته في المدافعة بين الأولياء،

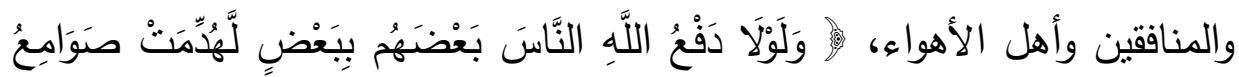

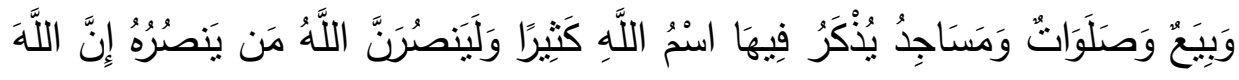

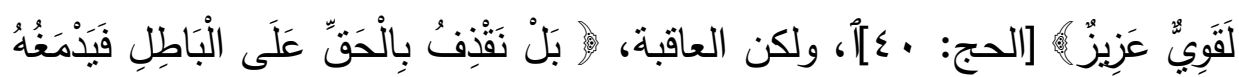

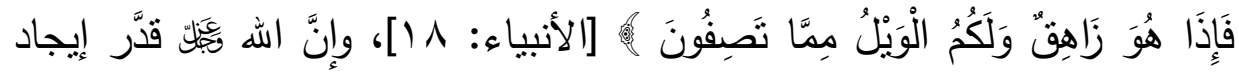
المنافقين في كل زمن وحين، حتى في زمن سبد المرسلين، فذاك عبد الله بن أُبي بن سلول رأس المنافقين، وأمَّا اليوم فقد تطور النّفاق، وتغيَّرت أساليبه وطريقة صراعه للحق المبين، وقد كانوا في السَّابق ومع قوة الإسلام يُخْفُونَ كفرهم وعنادهم، واليوم صاروا يُعلِنون كفرهم ومبادههم القائمة على إنكار وجود اله أو ولي

(*) أستاذ مشارك بقسم العلوم الشرعية - كلية الملك فهد الأمنية - المملكة العربية السعودية. 
التشكيك فيه وفي حكمه وألوهيته، ويثيْعون نهجهم وسط وبين أبناء المسلمين بلا خوفٍ ولا وجلٍ تحت مبدأ الحرية الثخصية أو حرية التعبير ونحو ذلك، مما يؤثز تأثنرًا خطيرًا على ثقافة الجيل ومبادئه التي نشأ عليها، ويجَرِّوُهم على كل ما هو دون ذللك ما دام أنَّهم تطاولوا على الذات الإلهية.

وكما أنَّ الغلو والإرهاب انحراف فكري وخطر على أمن المجتمعات، فإني لا أبالغ إذا قلتُ بأنَّ الإحاد كذلك انحراف عقدي وفكري وخطر على أمن المجتمع المسلم وضرورياته الدينية والعقلية والنَّسية والمالية والعرضية.

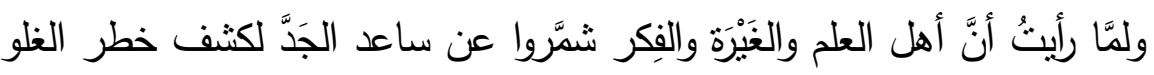
والإرهاب، وعُقدت لأجله الندوات والمؤتمرات، وهذا حق وجُهـ لا ينبغي تركه، رأيتُ في مقابلهِ نقصًا لا ينبغي تركه، كذلك في بيان خطر نقيضه وهو الإفراط المُتَتَّل اليوم

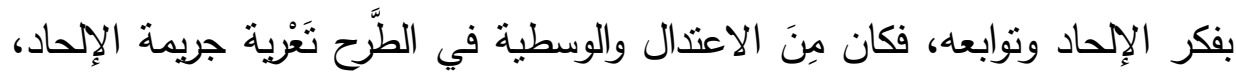
وبيان خطره حتى يضيق الخِناق على طرفي الانحراف الفكري (الإفراط والتقربط)، ويعٌّ الاعتدال والوسطية في المجتمعات، وكان هذا سبب اختيار الموضوع، ولم أجد دراسات سابقة تحدثت عن هذا الموضوع بهذا النحو المرسوم في الخِطة. 
د. د عبد المجيا بن صالح المنصور عـ

\section{أهداف البحث}

1 - إثبات أنَّ هناك علاقة بين الجريمة والإلحاد. r-بيان أنَّ جربمة الإحاد تُعنبر أحد مهدات الأمن الفكري التي تهد أمن وسلادة فِكر المجتمع المسلم.

ب-إثبات أنَّ جريمة الإلحاد انحراف فكري ومَيل عن قيم ومعايير ومعتقدات المجتمع المسلم، ومَيل عَنِ الوسطية والاعتدال الذي جاءت به شربعتنا الغراء. ع- إثبات أنَّ جريمة الإلحاد تُهدد الضروريات الخمس التي اتفقت عليها الشرائع، ومِنْ

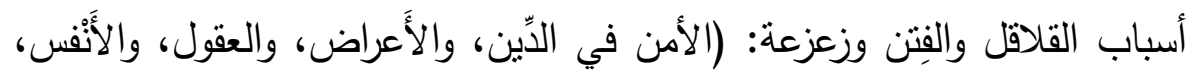

وقد اجتهدتُ في ذلك حسب علمي وجهدي، والله المسؤول أن يوفَّق ويُسدد

\section{خطة البحث}

\section{وقد جاء رسم خطة هذا البحث كالآتي:}

تمهيد: في تعريف مصطلحات العنوان، وفيه أربعة مطالب:

المطلب الأول: تعريف الإلحاد لغةً واصطلاحًا.

المطلب الثاني: تعريف الجريمة لغةً واصطلاحًا.

المطلب الثالث: التعريف بالضروريات الخَمس.

المطلب الرابع: علاقة الإلحاد بالجريمة.

المبحث الأول: أثر جريمة الإلحاد على حفظ ضرورة الدين.

المبحث الثاني: أثز جريمة الإلحاد على حفظ ضرورة النفس.

المبحث الثالث: أثز جريمة الإلحاد على حفظ ضرورة العقل.

المبحث الرابع: أثز جريمة الإلحاد على حفظ ضرورة العِرض.

المبحث الخامس: أثز جريمة الإلحاد على حفظ ضرورة المال.

الخاتمة: وفيها النتائج. 


\section{منهج البحث}

هذه الخُطة التي سِرثُ عليها في إعداد هذا البحث، واتبعتُ فيها المنهج المعروف عند الباحثين، من تصوير المسألة إذا احتاج الأمر إلى ذلك، ونت ونتئيق

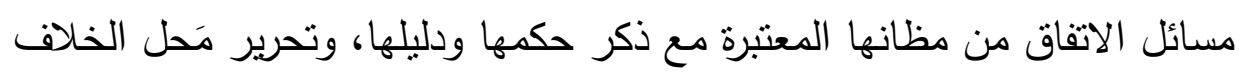

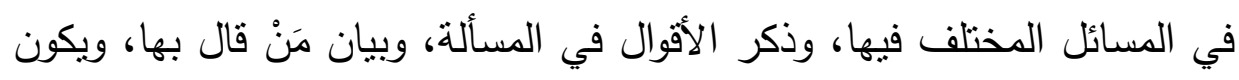

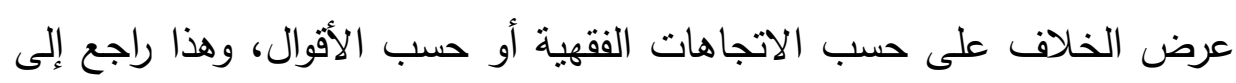

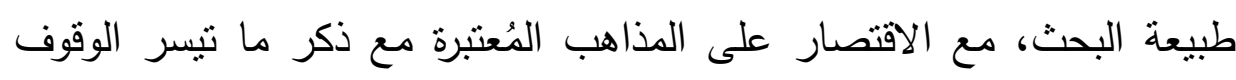

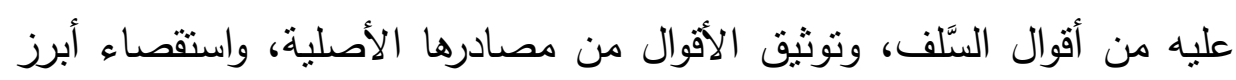

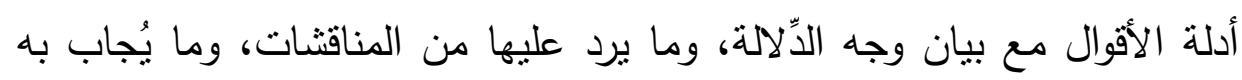

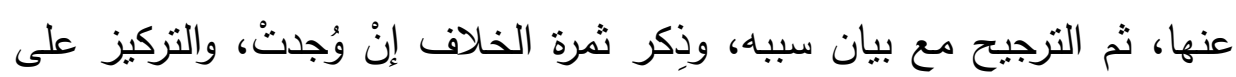

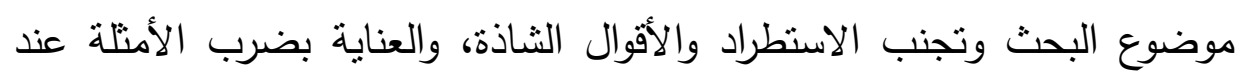

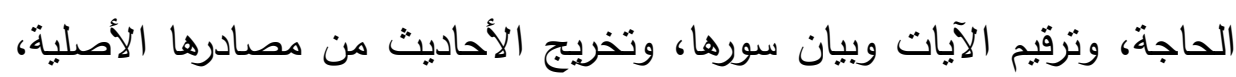

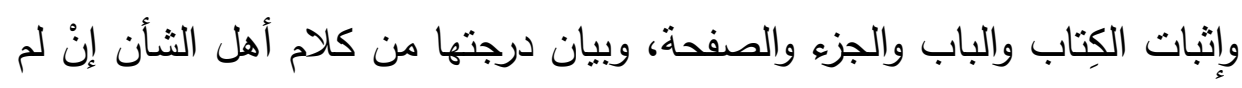

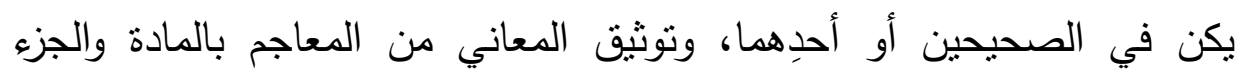

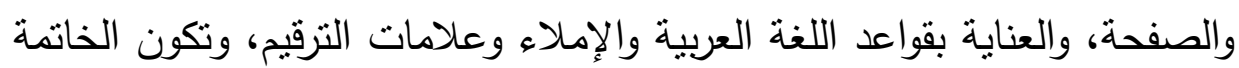

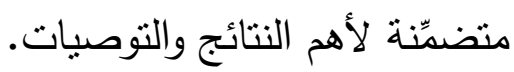


ב د . عبد المجيد بن صالح المنصور عـ

\section{تمهيد}

في تعريف مصطلحاث العنوان

وفيه أربعة مطالب:

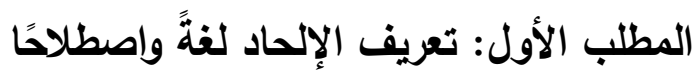

فيه فرعان:

الفرع الأول: الإلحاد في اللغة:

أصل الإلحاد: الميل عن القصد، والعدول عن الثيء، ولَحَدَ في الآدِين يلحد

وألحد: مال وعَدَل، وقيل: لحد: مال وجَار، و المُلحد: العادل عن الحق المُدخل

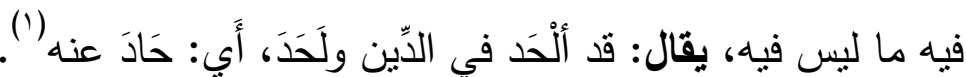

وقال ابن فارس: "اللام والحاء والدال أصل يدل على مَيل عن استقامة،

يقال: ألحد الرجل، إذا مال عن طريقة الحق والإيمان"|(').

الفرع الثاني: الإلحاد في الاصطلاح:

الإلحاد: لفظ مستخدم في عدة مواضع من القرآن، وقيل في تعريفه عدة

تعريفات، ومنها تعريف الطبري: "الإلحاد في الدين وهو المعاندة بالعدول عنه

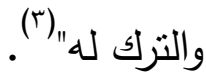

وفي الاصطلاح المعاصر هو : مذهب فلسفي يقوم على فكرة عدمية أساسها

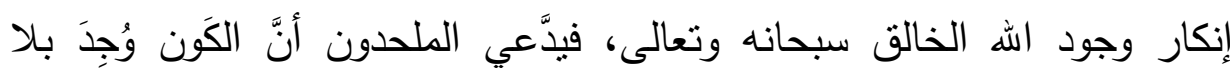

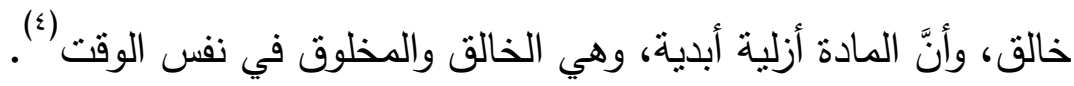

وهذا المعنى هو المقصود من هذا البحث.

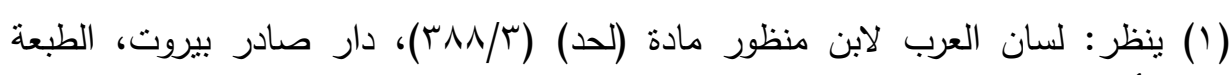
الأولى.

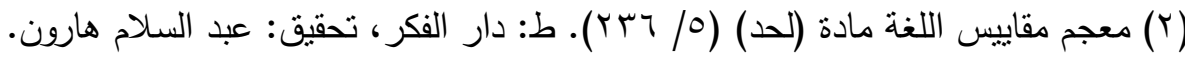

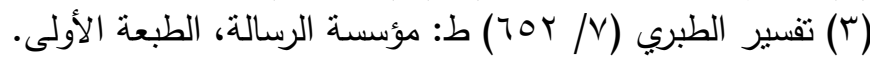

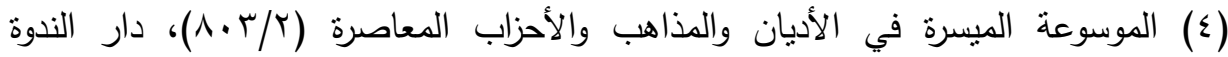

العالمية، الطبعة الرابعة. 


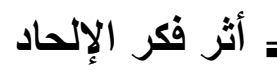

المطلب الثاني: تعريف الجريمة لغة واصطلاحًا وفيه فرعان:

الفرع الأول: الجريمة في اللغة:

الجريمة في اللغةة: مِنْ مادة (جَرَمَ) أي: أذنب واكتسب الإثم، والمُجرم:

المُذِنب، والجرم: التعدي والذنب، والجُرْم مصدر، والجارِم الذي يَجْرِم نَفْسَه وقومه شرًا، وفلان له جريمة إليّ أي: جُرْم، والجارمُ: الجاني (') وفي الحديث: „أعظم

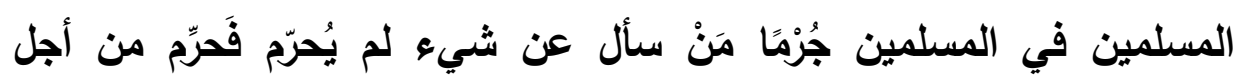

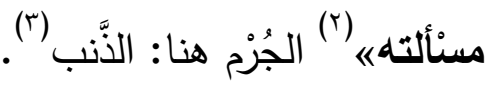

الفرع الثاني: الجريمة في الاصطلاح:

الجريمة في الاصطلاح لها معنيان عام وخاص:

فالتعريف العام: هو فعل ما نهى الله عنه، وعصيان ما أمر الله به، أو أو

بعبارة أعم: هي عصيان ما أمر الله به بحكم الشرع الشريف (؛)، أو معصية الله

ومعصية رسوله عليوسلمه (0).

فالجريمة بهذا المعنى تعم كل معصية، وتتشمل ما كان له عقاب في الدنيا أو الآخرة؛ لأن مِنْ الجرائم ما هو مستتز في النَّس البشربة، ويعاقب عليها في الآخرة

(1) يُنظر : لسان العرب مادة (جرم) (Y / • (9)، المصباح المنير مادة (جرم)، ص: (00).

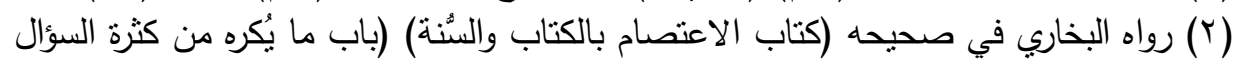

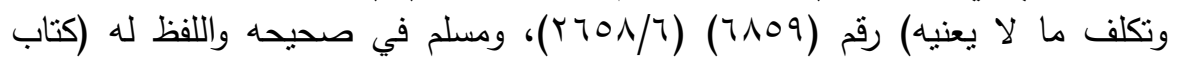

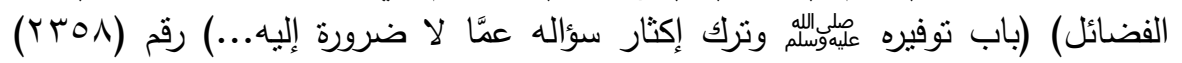

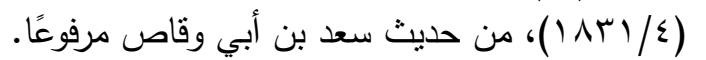

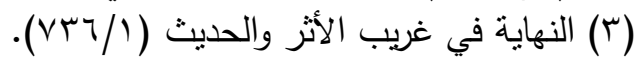

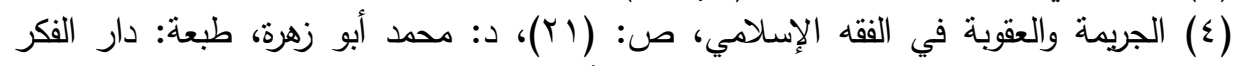

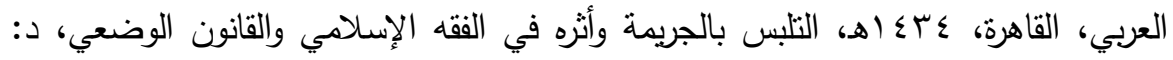
بسيوني إبراهيم، ص: اهرة، عاء (1 (1)، دار الجامعة الجديدة، الإسكندرية.

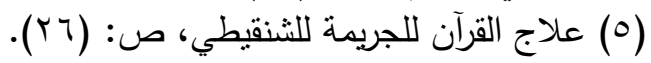




\section{د. دبد المجيد بن صالح المنصور عـ}

كالحقد والحسد وغيرها"')، وكنلك يثمل اعتداء المره على نفسه، أو اعتدائه على حقِّ

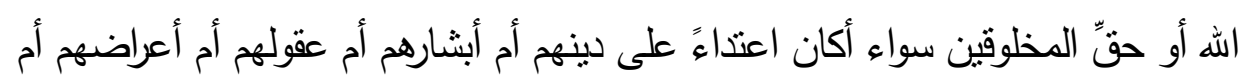
أموالهم؛ إذ كل ذلك معصية لله ورسوله عليهوليلم.

وتعربف الجريمة على هذا النحو يكون مرادفًا لتعريف الفقهاء لها بأنها: إتيان

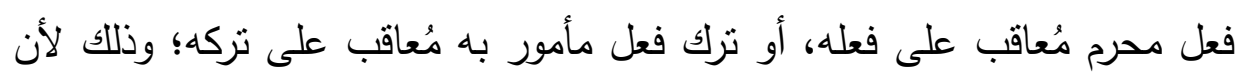
الله تعالى قرر عقابًا لكل مَنْ يُخالف أوامره ونواهيه، وهو إمَّا أنْ يكون عقابًا دنبويًاً

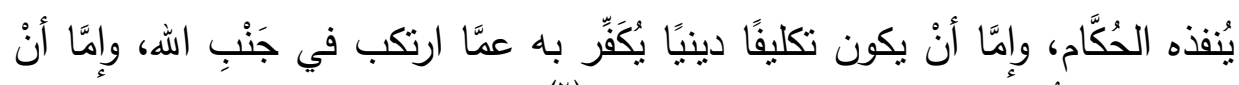

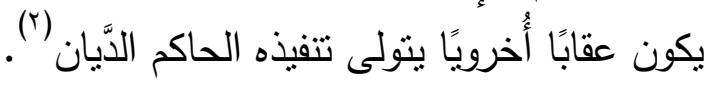
وأمَّا التعريف الخاص: فلم أجد للفقهاء فيه تعريفًا اصطلاحيًا إلَّا ما ذكره الماوردي لتوني والقاضي أبو بعلى بأن الجرائم: محظورات شرعية زَجر الله عنها بحد أو تعزير (َ)،

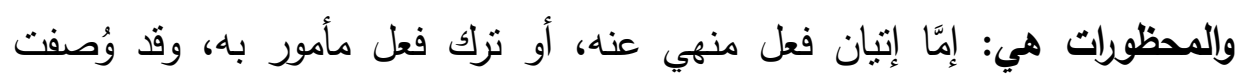

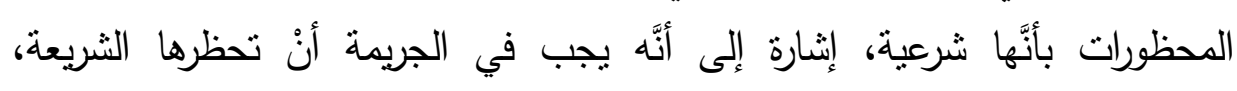
فالجريمة إذن: هي إتيان فعل مُحرم مُعاقب على فعله، أو نزك فعل مُحرم الترك مُعاقب

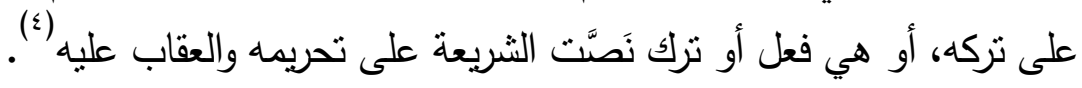
ويتبيَّن من تعريف الجريمة أن الفعل أم الترك لا يُعتبر جريمة إلَّا إذا تقررت

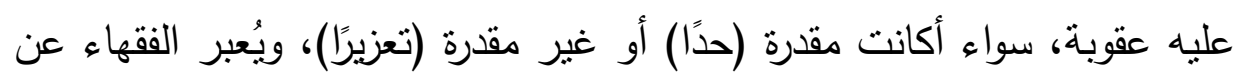
العقوبات بالأجزية، ومفردها: جزاء، فإنْ لم تكن على الفِعل أو الترك عقوبة فليس بجريمة، وتتفق الثريعة تمام الاتفاق مع القوانين الوضعية الحديثة في تعريف الجريمة، فهذه القوانين تُعرف الجريمة بأنها: إمَّا عمل يُحرمه القانون، وإمَّا

$$
\begin{aligned}
& \text { (التشريع الجنائي الإسلامي د: العجلان، ص: (·) (Y). }
\end{aligned}
$$

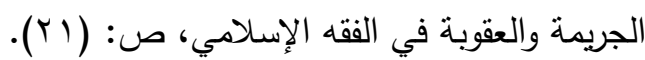

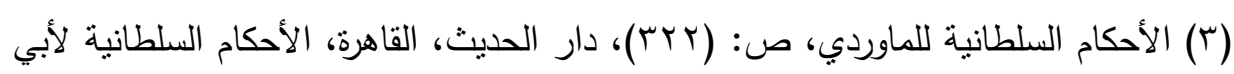

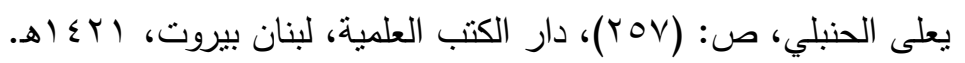

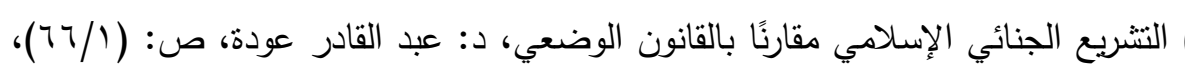

$$
\text { دار الكتاب العربي، بيروت. }
$$


امتتاع عن عملٍ يقضي به القانون، ولا يُعتبر الفعل أو الترك جريمة في نظر الإدرال القوانين الوضعية إلَّ إذا كان معاقبًا عليه طبقًا للتشريع الجنائي ' ل. وممَّا سبق يتبيَّن أنَّ: الجريمة بالمعنى العام أَثمل من ناحية زمن العقوبة،

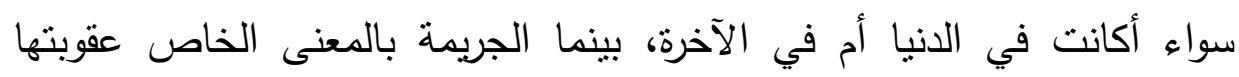
دنيوية، والله أعلم. المطلب الثالث: تعريف الضروريات الخمس

$$
\text { والفرع الأول: تعريف الضروريات: }
$$

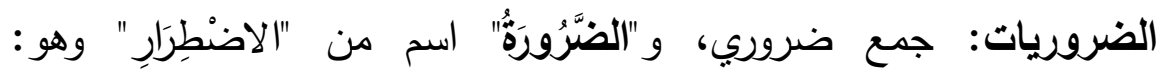

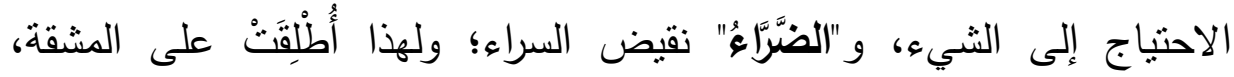

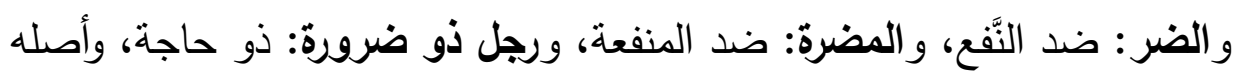

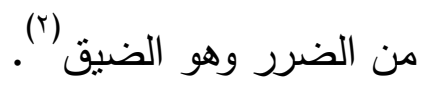

واصطلاحًا: عرَّف الثناطبي الضروريات بأنها: "هي التي لا بد منها في قيام

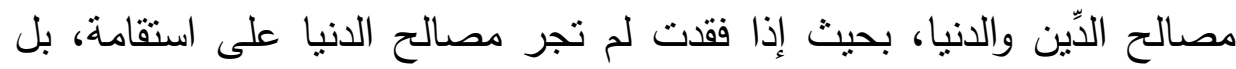

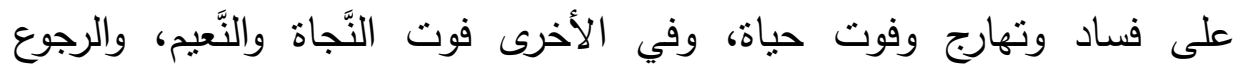

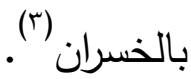

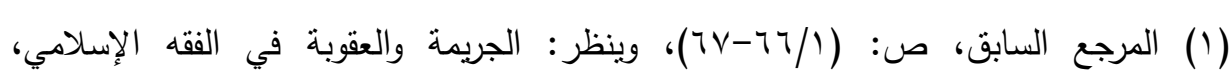
ص: (Y) (Y)، التلبس بالجريمة، ص: (IV) (IV) (IV).

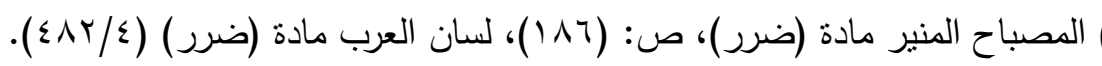

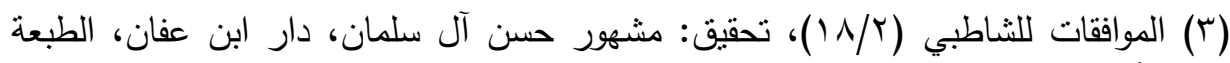

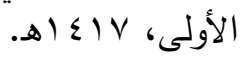


الفرع الثاني: الضروريات الخمس

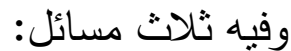

المسألة الأولى: ماهية الضروريات الخمس وعددها وسبب تسميتها بذلك: بعد تتبع واستقراء طويلين انتهى العلماء إلى ملاحظة أن مقاصد الثريعة ومصالحها الكبرى التي تدور حولها معظم أحكامها أو كلها، تجتمع في مصالح خمس سموها: الضروريات الخمس، وسماها بعضهم: الأصول الخمسة، والكليات

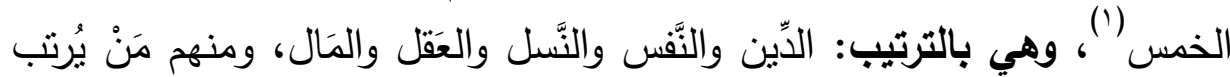
العقل قبل النَّل، ولعل أول كَنْ ذكرها واضحة كاملة هو الإمام الغزالي؛ حيث وني قال: ومقصود الشرع من الخلق خمسة وهو أن يحفظ عليهم دينهم ونفسهم وعقلهم ونسلهم ومالهم، فكل ما يتضمن حفظ هذه الأصول الخمسة فهو مصلحة، وكل ما ونا

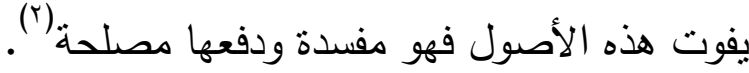

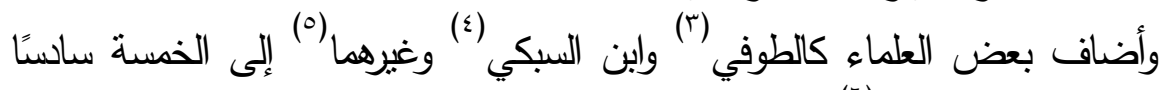
وهو : ضرورة حفظ العرض (؟)

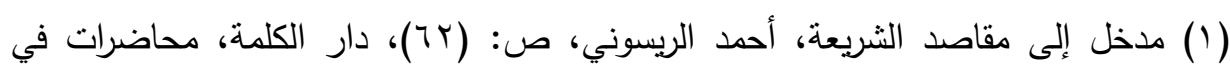

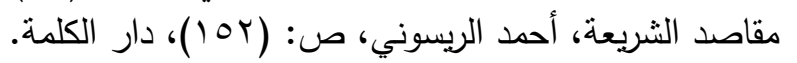

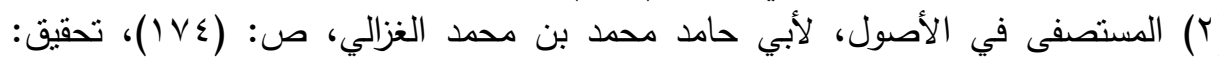

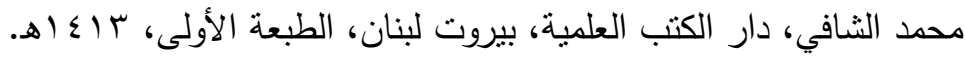

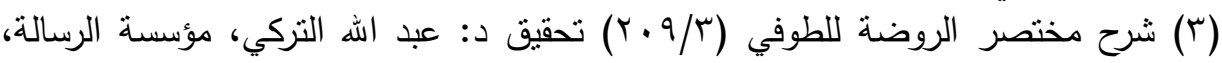

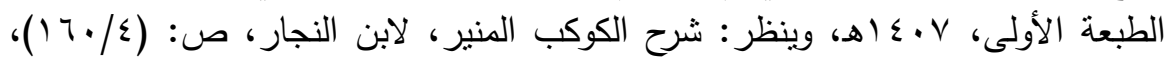

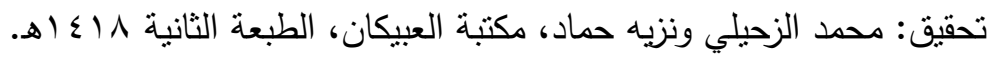

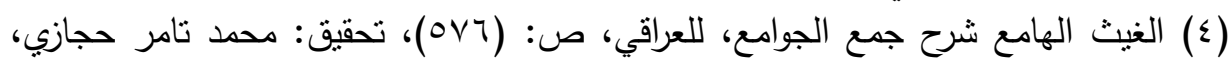

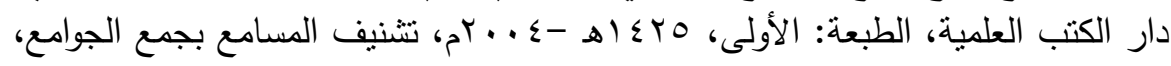

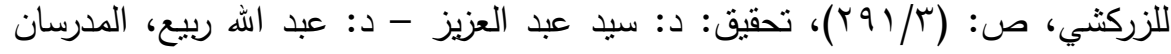

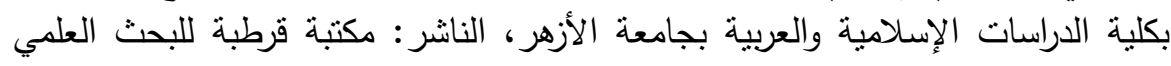
وإحياء التراث - توزيع المكتبة المكية.

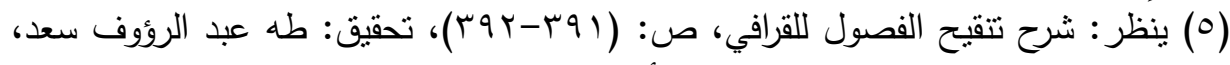

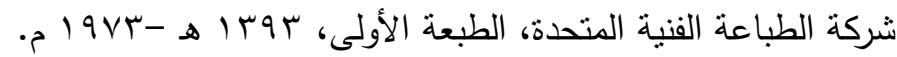

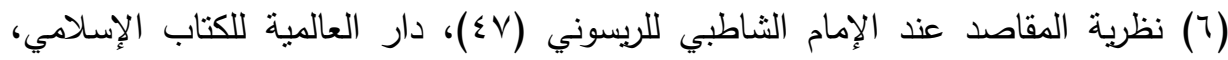




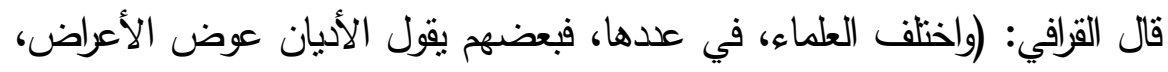

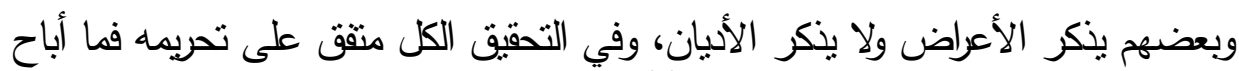
الله تعالى العِرض بالقفت والهبّاب قط....) ('). وقال الثشاطبي: (وإن ألدق بالضروريات حفظ العِرض؛ فله في الكتاب أصل فله

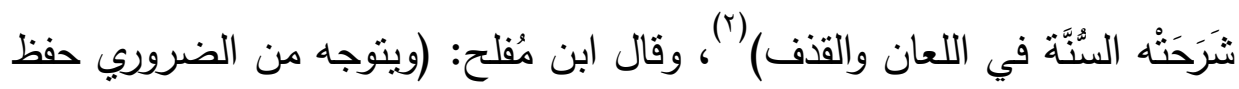

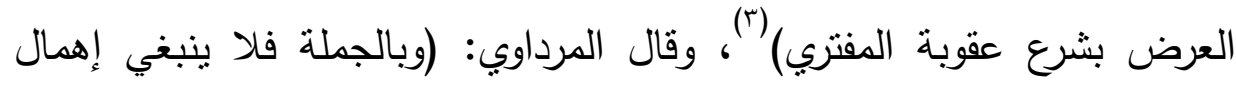

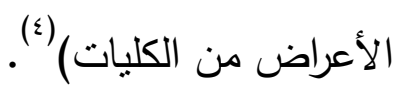
وقد دافع الزركثي عن هذه الزيادة إلى الضروريات الخمس فقال: (وقد زاد

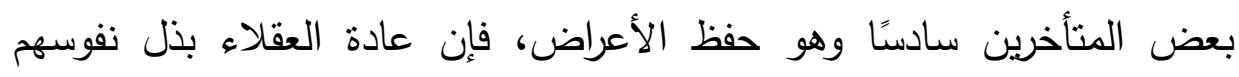

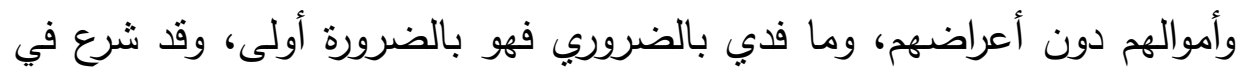

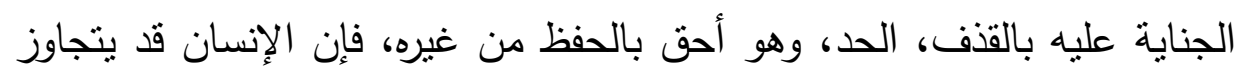

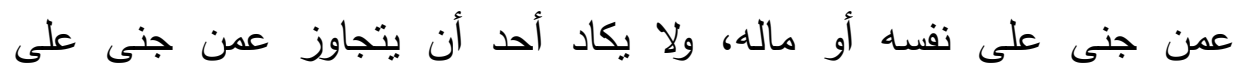
عرضه (') ولهذا يقول قائلهم:

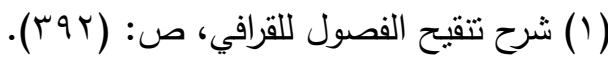

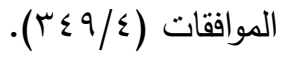

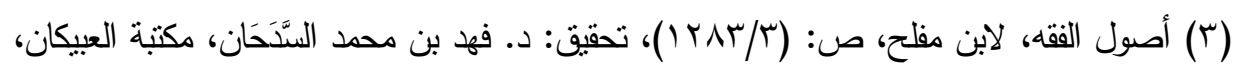

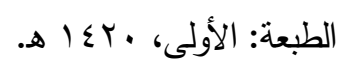

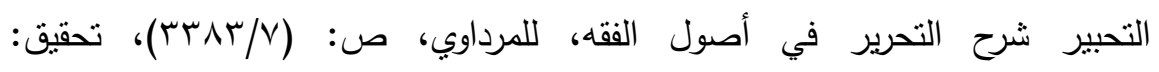

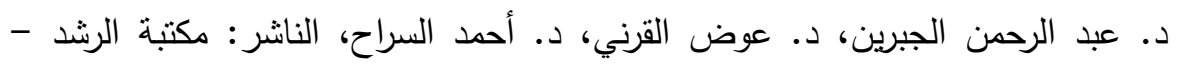

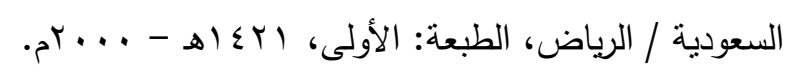

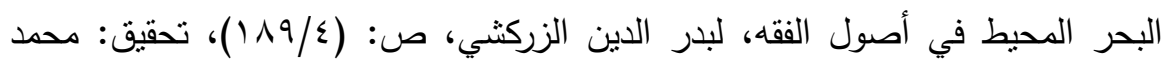

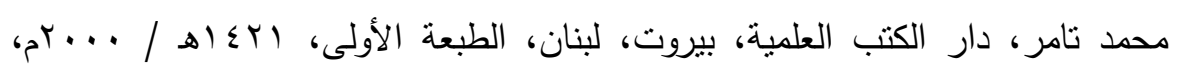

مصدر الكتاب: موقع مكتبة المدينة الرقمية. 


\section{د. دبا المجيد بن صالح المنصور عـ}

يهون علينا أن تصاب جسومنا وتسلم أعراض لنا وعقول (')

وبعض الأصوليين لا يضيفون العِرض، لكنهم ينوِّون في بعض هذه الأسماء لهذه

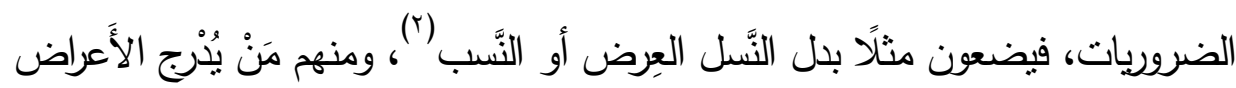

في النَّل (r).

ويرى الثاطبي أنَّ مِنَ المقاصد الكلية للشريعة: (أن يكون المكلَّف داخلًا تحت قانون معين مِنْ تكاليف الثََّع في جميع تصرفاته اعتقادًا وقولًا وعملًا فلا يكون متبعًا لهواه كالبهيمة المسيَّبة حتى يرتاض بلجام الشرع) (ء). وقد ذهب عدد من العلماء إلى أنَّ حفظ هذه الضروريات الخمس ليس من خصوصيات الثريعة الإسلامية، بل هو مِمَّا اتفقت على حفظها كآفة المِلل والثرائع، قال الثاطبي: (فقد اتفقت الأمة، بل سائر المِلل على أنَّ الثربعة وُضِعَتْْ للمحافظة على الضروريات الخمس، وهي: الدِّين، والنَّس،، والنَّسل، والمال، والعقل، وعلمها عند

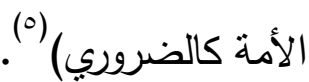

وسُيمت بالضروريات؛ لأنها مصالح لا يمكن الاستغناء عنها، ولا تتنظم

الحياة بدونها.

فمن دون حِظ الدِّين يتحول الناس إلى همج رعاع، يفقدون فيها إنسانيتهم

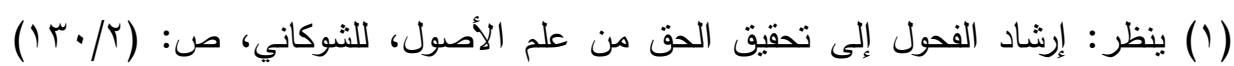

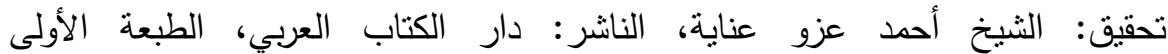

$.01999-81 \leqslant 19$

$$
\text { (Y) محاضرات في مقاصد الشريعة (T ( I )). }
$$

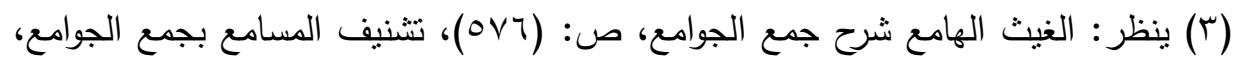

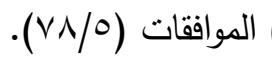

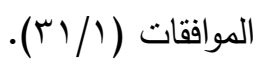


وكرامتهم ورسالتهم وحِكمة وجودهم وحياتهم، وخسارة آخرتهم، ومن دون حفظ الاحت

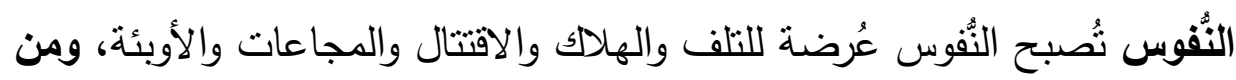

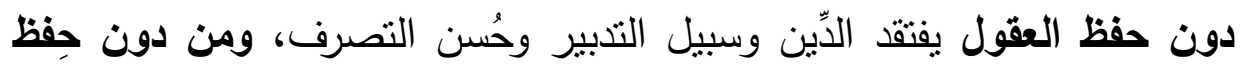

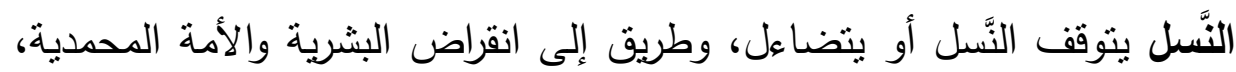

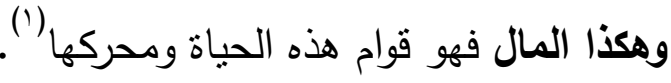
وأمَّا وجه تسميتها بالكليات فهو أنَّ كل واحدة من هذه المصالح حِفظها لبس

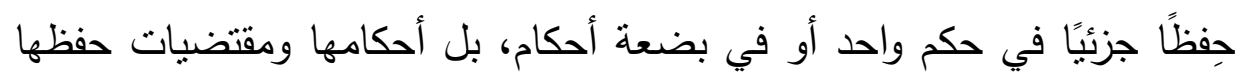
وأسبابها مبثوثة في الثريعة، في أحكام جزئية لا تُحصى، وفي أحكام وإن ومبادئ عامة متعددة؛ ولذلك تجدها في كل جوانب الثريعة، كما أنَّ نسميتها بالكلية باعنبار أنَّها مصالح عامة لمجموع الناس وكلهم لا تختص بفئة أو طائفة معينة (†)

\section{المسألة الثانية: المراد بحفظ الضروريات الخمس:}

المراد بحفظ الضروريات الخمس تحقيق الأمن لها، وإيجادها وتحقيقها

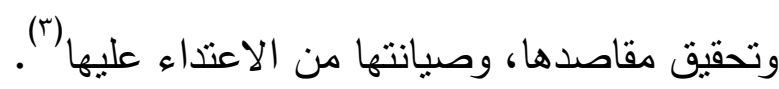

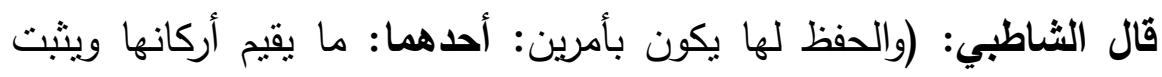

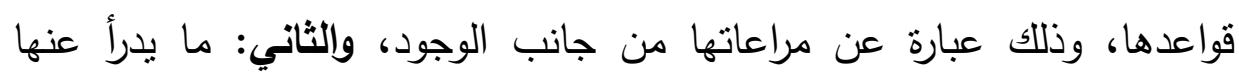

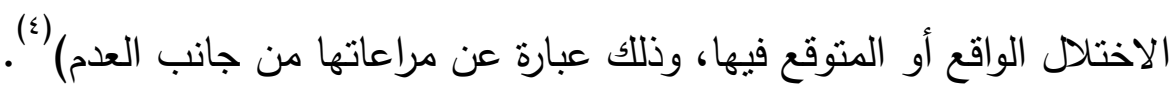

$$
\begin{aligned}
& \text { (1) ينظر : محاضرات في مقاصد الثريعة (100-109-104) (107). } \\
& \text { (Y) ينظر : محاضرات في مقاصد الثريعة (107-107) (107-100). }
\end{aligned}
$$

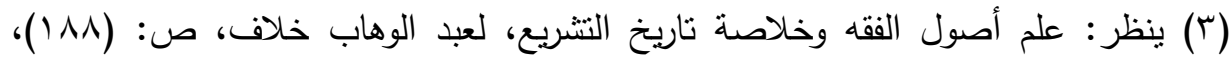

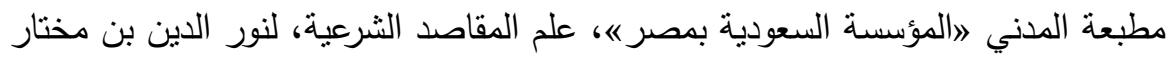

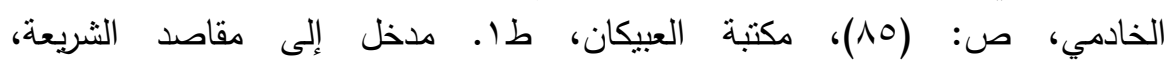




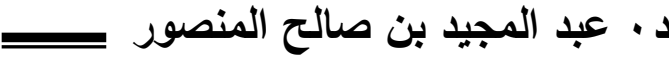

\section{وتفصيلها بما يلي:}

\section{الأول: حفظ الدين:}

حفظ الدِّين يُعد أكبر الكليات الخمس وأرقاها، ومعناه: تثبيت أركان الدِّين وأحكامه في الوجود الإنساني والحياة الكونية، وكذلك العمل على إبعاد ما يخالف دين الله ويعارضه، كالبدع ونشر الكُفر والرذيلة والإلحاد والرّّدة، والتهاون في أداء

واجبات التكليف (')

ومن أجل حفظ الدِّين شُرِعَ قتل المرتد والداعى إلى الرِّدة، وعقوبة المبتدع الداعي إلى البدعة(؟)، وشُرع الإيمان والنُّطق بالثهادنين والصلاة والزكاة والصيام والحج، والدعوة إليه، والجهاد في سبيل الله، والأمر بالمعروف والنَّهي عن المنكر، الهُه وسائر الأعمال والأقوال التي تُحقق الدِّين في النُّْوس والحياة، كالأذكار والَقُرُكَات والوعظ والإرشاد والنُّحح وبناء المساجد والمدارس، وتبجيل العُلماء والمُصلحين والأُعاة وغير ذلك (r).

\section{الثاني: حفظ النفس:}

ومعناه: مراعاة حق النَّفس في الحياة والسَّلامة والكرامة والعزَّة، ومن أجل حفظ النفس شُرعت أحكام كثيرة منها: منع القتل، وتشريع القِصَاص، وتحريم الإلقاء بالنَّفس إلى التَّككة، ومنع التمثيل والتشويه، ومعاقبة المحاربين وقُطَّاع الطرق والمستخفين من حرمة النَّس البشرية، ومنع الاستنساخ البشري والتلاعب بالجينات، والمتاجرة بالأعضاء والتشريح لغير ضرورة معتبرة، وحرق أجساد الموتى، كما أمر

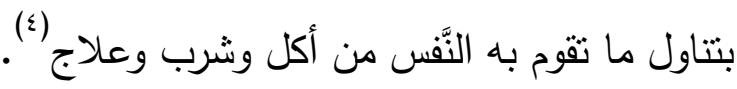
(Y) (1) علم المقاصد الشرعية، للخادمي، ص: (1) (1).

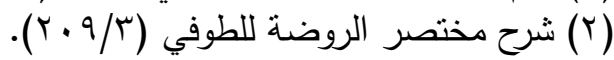

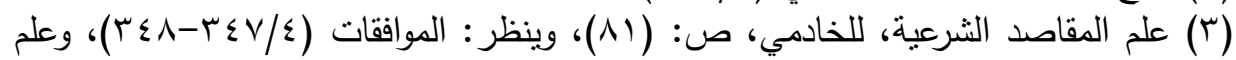

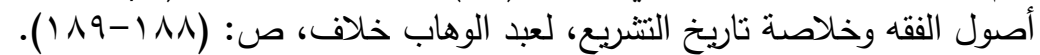

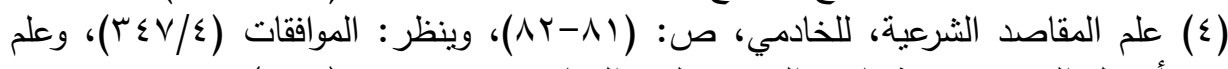

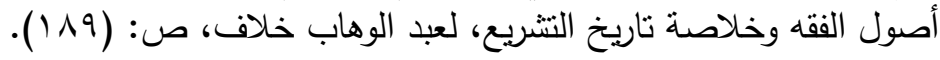




\section{الثالث: عفظ العقل:}

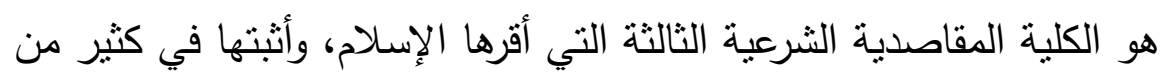
المواضع والمواطن، من ذلك: اهتمامه بالعقل وجعله شرطًا في التكليف فهمًا وتتزيلًا، ومناطًا في التعامل مع أحوال النَّفس والكَون، اكتنثافًا لأسرارهما واستتباطًا

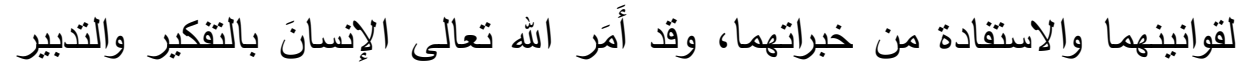

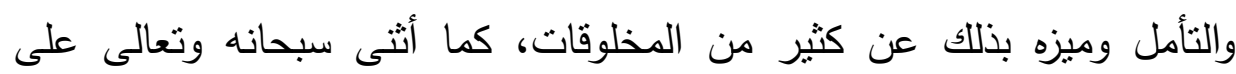
أصحاب العقول السليمة من المجتهدين والمفكِرين والمتدبِّرين. وكل هذا دليل على مكانة العقل في الإسلام، ودوره الملحوظ في فهم الأحكام واستتباطها وتطبيقها.

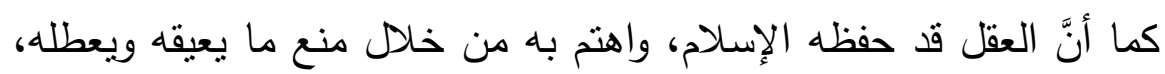

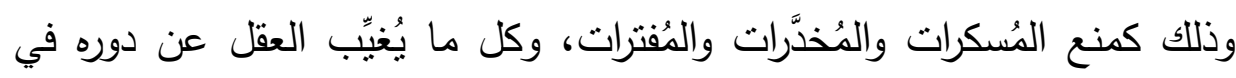

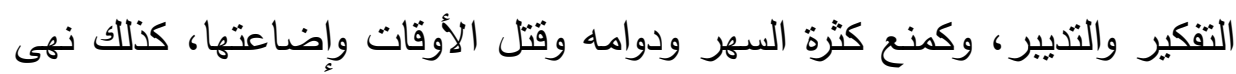

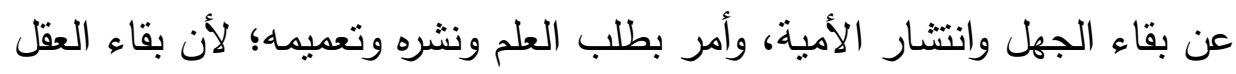

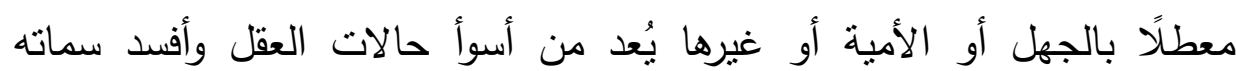

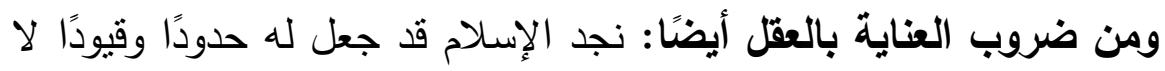

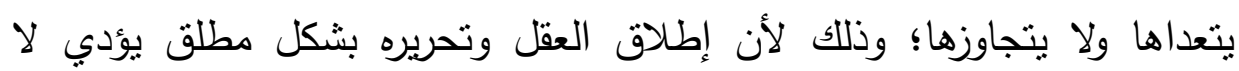

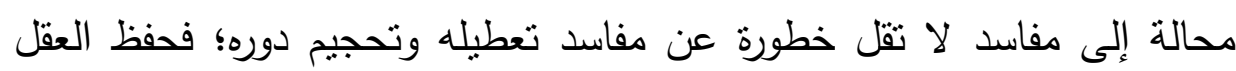

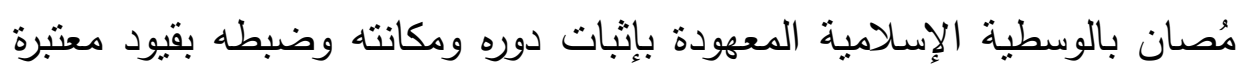
وضوابط معلومة '(')

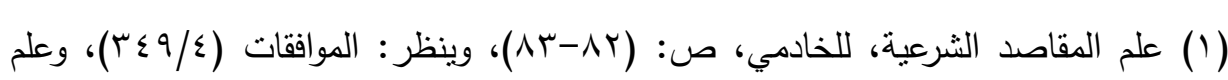

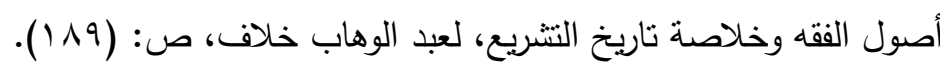

$$
\begin{aligned}
& -11 \mathrm{r}-
\end{aligned}
$$




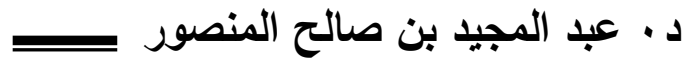

ولأجل ذلك نلاحظ أن الثريعة الإسلامية تُحارب الانحرافات الفكرية الضالة الغالية أو الجافية، وتمنع من التسويق لها أو السَّماح بترويجها كالزندقة والإلحاد والغُلو والنَّطرف، كل ذلك حماية لضرورة العقل بالإضافة لضرورة الدِّين.

\section{الرابع: حفظ النسل والعرض والنسب:}

حفظ النسل معناه: التناسل والتوالد لإعمار الكون، وحفظ النسب معناه:

القيام بالتتاسل المشروع عن طريق العلاقة الزوجية الثرعية، وليس التناسل الفوضوي كما هو عند الحيوانات، أو في بعض المجتمعات الإباحية المادية التي لا تعلم منها لا أصول ولا فروع ولا آباء ولا أبناء؛ إذ يعيش الفرد أحيانًا كل حياته دون أن يعلم مَنْ أبوه ومَنْ أمه. لَه.

وحفظ العرض معناه: صيانة الكرامة والعِفة والثََّّف، والمعاني الثالثة المذكورة "النَّسل والنَّسب والعِرض" تُعد المقصد الثرعي الكُلي الرابع الذي أقره الإسلام في نصوصه وأحكامه، وأثنتها وجذَّرَه من خلال نشريعات عدة نذكر منها: أ- الحث على الزواج والترغيب فيه وتخفيف أعبائه وتيسير مصروفاته.

ب- منع الزنا، وسد منافذه وذرائعه، كالخلوة والتبرج والنظرة بشهوة والمماسة والالتصاق. ج- معاقبة المنحرفين الممارسين للزنا أو اللواط أو السِّحاق. د- الأمر بالتَّمسك بالأخلاق الفاضلة والقيم العليا، والنَّهي عن الرذائل

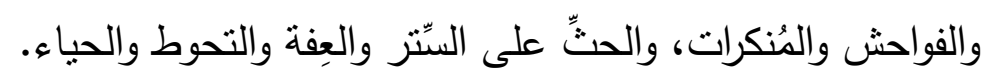
هـ - منع التبني، ووجوب أن يُدعى الإنسان بأبيه وليس بمتبنيه ' .

$$
\text { (1) علم المقاصد الثرعية، للخادمي، ص: (rی-^ی). }
$$


أثر فكر الإلحاد

الخامس: حفظ المال:

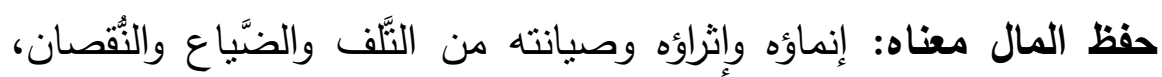

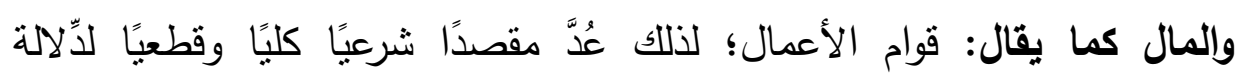

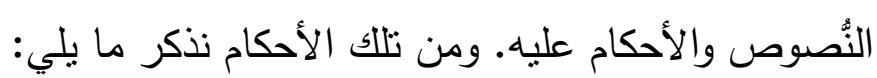

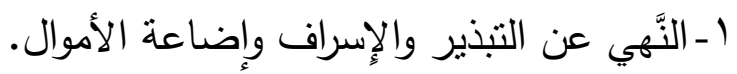

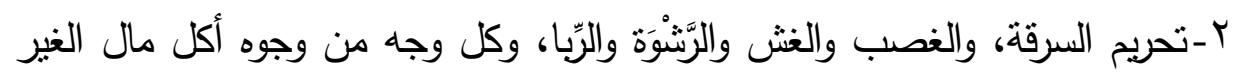
بالباطل.

r-معاقبة آكلي أموال النَّاس بالباطل بالحدود والتعزيرات، كمعاقبة السَّارق بقطع يده، والمُحارب أو قاطع الطريق بحد الحِرَابة. ع - تضمين المتلفات.

هـ منع اكتناز الأموال وتكديسها كي لا يُسهم في تعطيل ترويجها والاتنقاع بها والاستفادة منها (')

\section{المسألة الثالثة: مستتد العلماء في تحديد هذه الضروريات:}

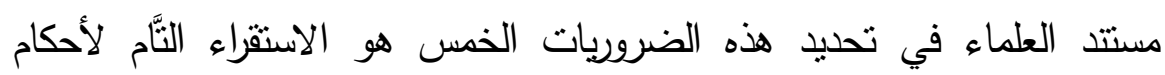

الثريعة؛ حيث وجدوها كلها تدور على هذه الضروريات أو ثُضي هن هن قريب أو بعيدإلى خذمتها ورعايتها (r).

ومِمًا يؤكد الأهمية البالغة لحفظ هذه الضروريات وصيانتها من الانتهاك

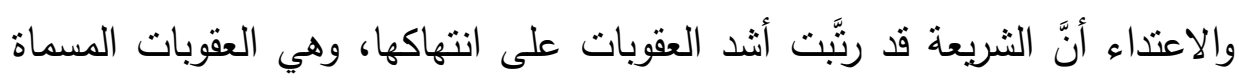

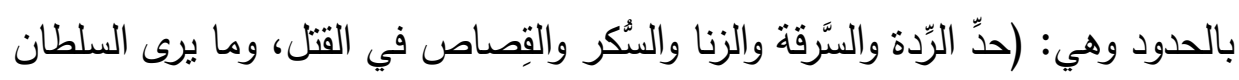

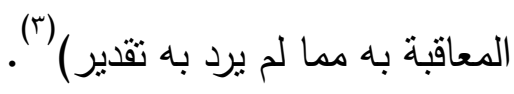

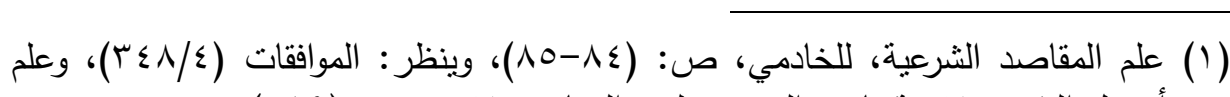

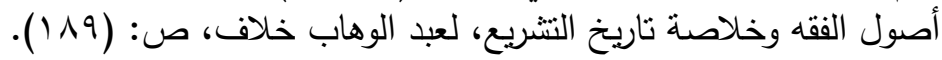

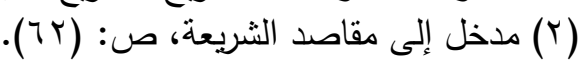

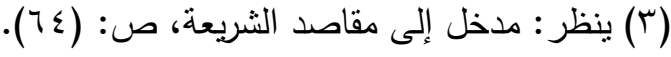

$$
\begin{aligned}
& -11 \leqslant-
\end{aligned}
$$




\section{د. د عبد المجيد بن صالح المنصور عـ}

ففي حدّ الرّدّة حفظ الدِّين، وفي حدِّ الحِرَابة حفظ النَّفس والمال، وفي حَدِّ السَّرِقة حفظ المال أيضًا، وفي حَدّ الزّنّا والقذف حفظ النَّسل، وفي حَدِ الخَمر حفظ

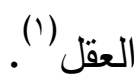

\section{المطلب الرابع: علاقة الإلحاد بالجريمة}

بعد أن عرفنا معنى الإلحاد في الاصطلاح، ومعنى الجريمة بمعناها العام والخاص، وعرفنا حقيقة الضروريات الخمس، ومعنى حفظها وتأمينها ثُنتِج لنا تلاك المقدمات نتيجة أن الإلحاد جريمة، بالمعنى العام، بلا شك؛ لأن الإلحاد يعني الكُفْرَ بالله، وعدم الإيمان بوجوده أو التشكيك به، ونسبة الخلق لغيره، وأبي جرم

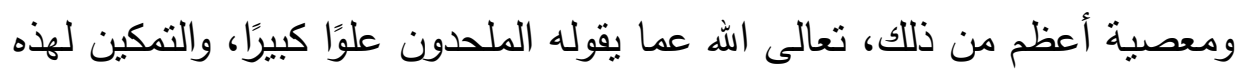
العقيدة الفاسدة ونشرها جريمة على الدِّين الإسلامي والثخصية الإسلامية والمجتمع لهي

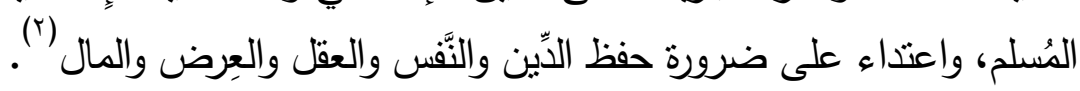
وكذلك الإلحاد جريمة بالمعنى الخاص إنْ صدرت مِنْ مسلم؛ لأنَّها ردة صريحة عن دين الله تعالى، وتُطبق عليه أحكام الرّّدة وعقوبتها في الفقه بـن الإسلامي، والرِّدَة مِنْ جرائم الحُدود.

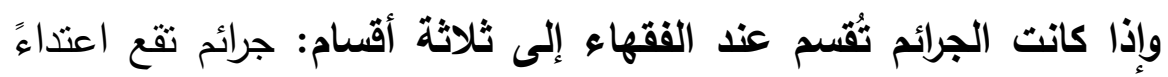
على حق الله جَلَّ شَأْنه، وجرائم تقع اعتداءً على حقِّ العبد، وجرائم تقع اعتداءً

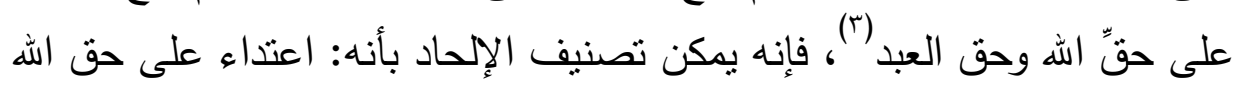

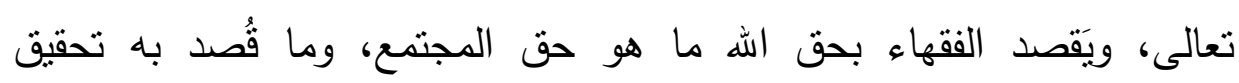

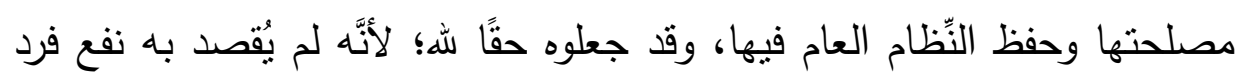
معين، وليس للأفراد -حكامًا أو محكومين - حق إسقاطه أو العفو عنه أو إهمال

(1) الفكر المقاصدي، قواعده وفوائده، أحمد الريسوني، ص: (ب⿳) (ب).

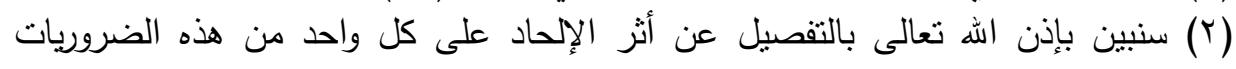

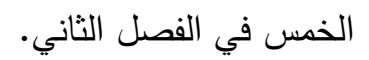

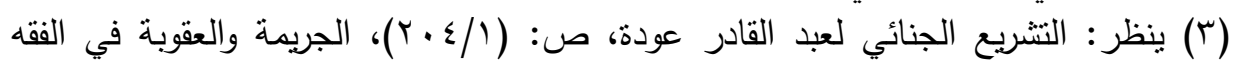

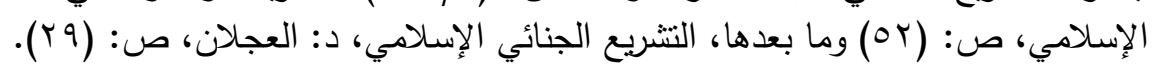




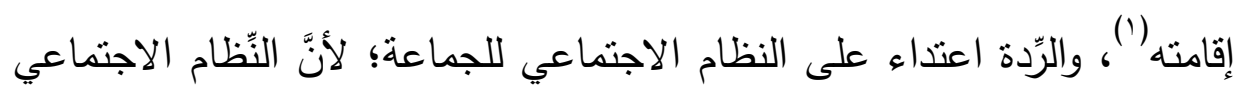

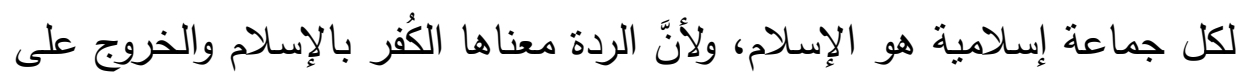

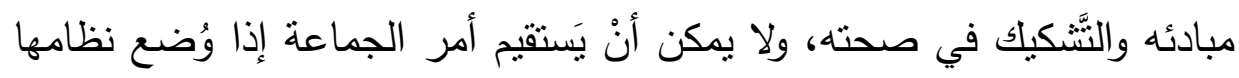

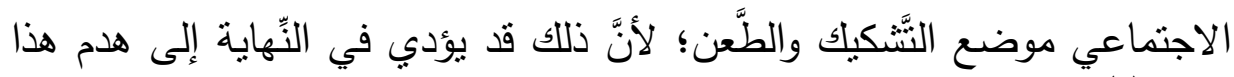

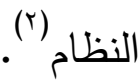

والفكر الإحادي يحاول توظيف الضروريات الخمس لتحقيق أهدافه، وهدم

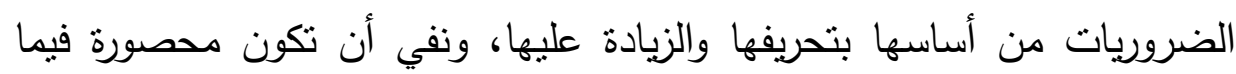

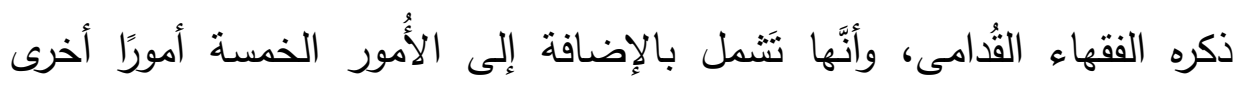

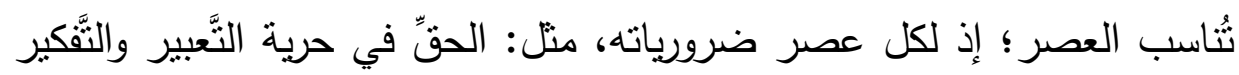

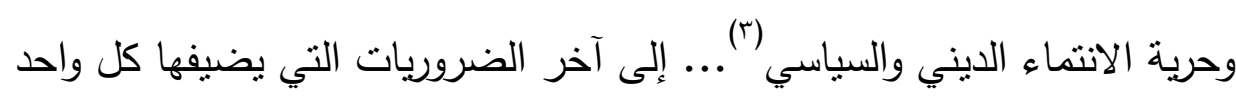

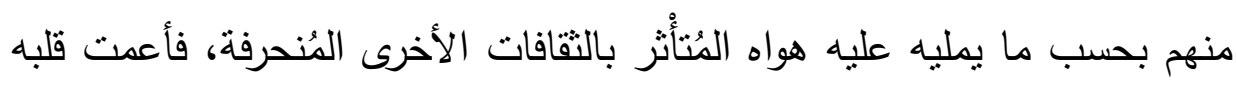
وعقله عن شمولية الثريعة الإسلامية وصلاحيتها لكل زمان ومكان.

وبعد أن عرفنا معنى الإحاد في الاصطلاح الحديث، وأن اعتباره جريمة

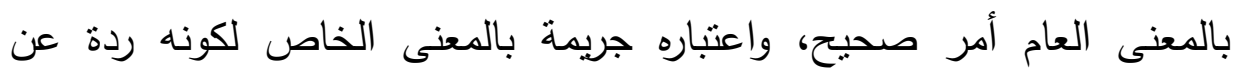

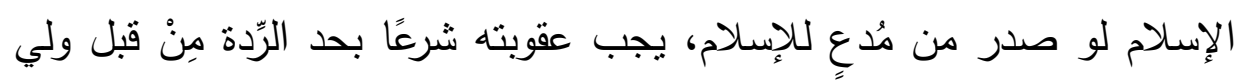

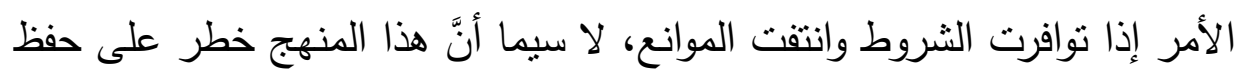

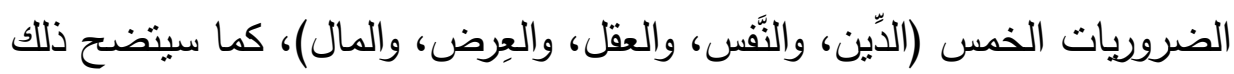

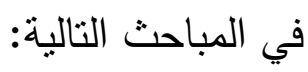

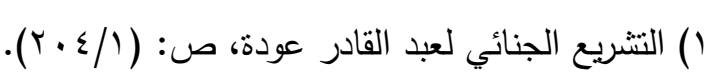

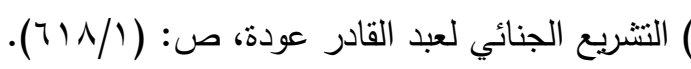

(ץ) ينظر : موقف الليبرالية العربية من محكمات الدين، دراسة نحليلية نقدية، مركز البحوث والدراسات

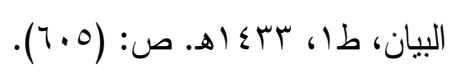


د · عبا المجيا بن صالح المنصور عـ

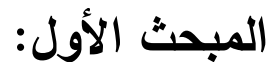

\section{أثز جريمة الإلحاد على حفظ ضرورة الدين}

سبث أنَّ حِظظ ضرورة الدّيّن أكبر الكليات الخمس وأرقاها، وأنَّه لا يتم إلا بتثيت أركان الدِّين وأحكامه في الوجود الإنساني والحياة الكونية، وكذلك العمل على إبعاد ما يُخالف دِين الله وبعارضه، وبالنَّظر البسيط في حقبقة الإحاد ومظاهره يتضح أنه يهدم ضرورة حفظ الدِّين، ويقوّض أركانه وأحكامه، ويُبطل محكماته، ولا يؤمن به، بل ويكذّبه، حيثُ يُنكر وجود الله وقدرته سبحانه وتعالى على الكَون والبَعث والنُّشور وإنكارهم للمعجزات الكونية ومعجزات الأنبياء وغيرها من المعتقدات التي تُشكل خطرًا كبيرًا على دِين المسلمين وعقيدة هذه البلاد لو تغلغل فيها وفي مؤسساتها -لا قدر الله-؛ لذا كان لزامًا علينا تجلية بعض أوجه هذه المعارضة والآثار على حفظ الدين بشكل عام وعلى حفظ دين هذه البلاد بشكل خاص، وبيان ذلك في المطلبين التاليين: المطلب الأول: أثز جريمة الإلحاد على الآّين بشكل عام الإحاد بكل اتجاهاته المعروفة لا يمكن أن بجتمع مع الدِّين إذا فُهمت حقيقة كل منها، فالديّين خضوع وانقياد وتصديق وإيمان، والإلحاد باتجاهاته المتعددة تحرر وتمرد وتكذيب واستكبار، والإلحاد بكل اتجاهاته إنسانية المصدر في تصوراته وتطبيقاته، بينما الدِّين وحي إلهي، ورسالة سماوية وعبودية بين خالق ومخلوق (')

وقد عمد الخطاب الإحادي إلى هدم الآّين كله عقيدة وعبادة وسلوكًا، وتقريغه من حقبقته ومحتواه ليكون خيالً هلاميًا لا لُبَّ فيه ولا روح، وتركزت هذه الجهود فى محورين رئيسين:

$$
\text { (1) موقف الليبرالية العربية من محكمات الدين، ص: (†^v). }
$$


الأول: توجيه النقد الهادم لمصادر التلقي ومناهج فهمها، فأبطلوا حجِّيَّة

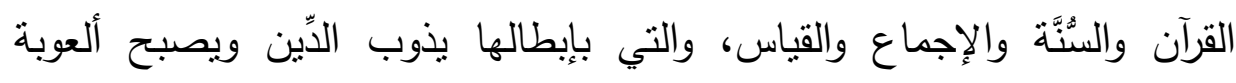

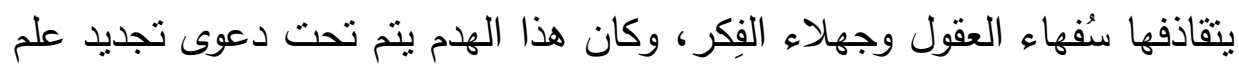
أصول الفقه.

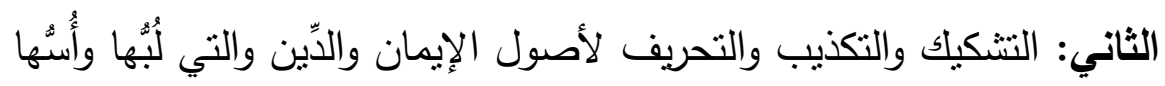
علم الغيب، ومنه: (الإيمان بالله وملائكته وكتبه ورسله واليوم الآخر والقدر خيره وشره)، تحت ذريعة تجديد أصول الدين أو علم الكلام الجديد '.

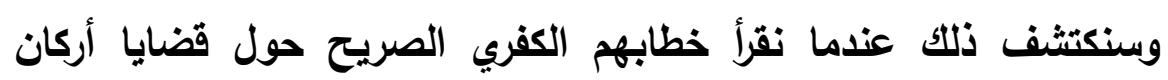
الإيمان وأصول الثريعة في الفروع التالية: الفرع الأول: موقف الملددين من الإيمان بالغيب: لإنيان

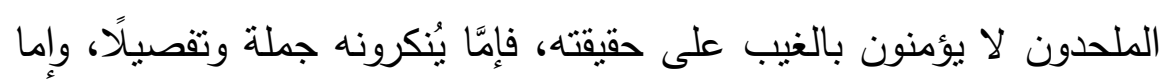

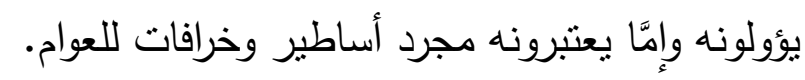

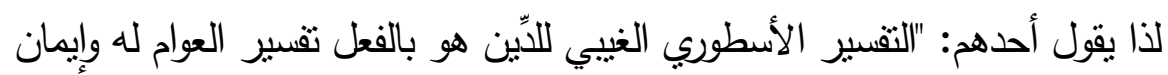

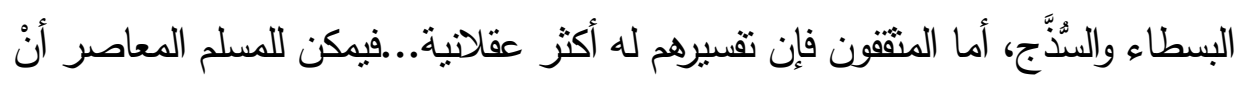

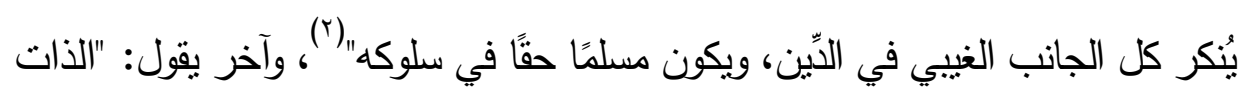

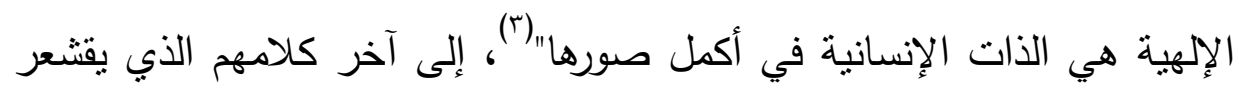
منه الجلد، ويُنزه الخالق سبحانه من ذكره.

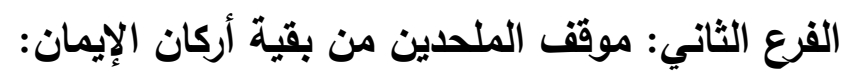

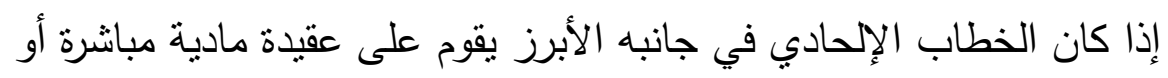

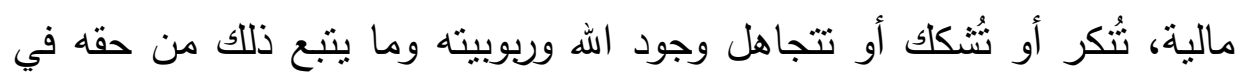

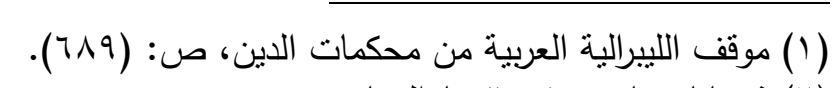

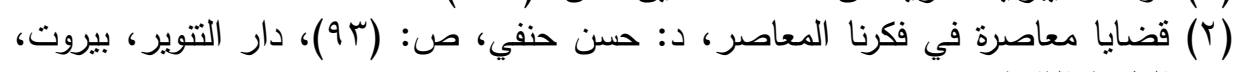

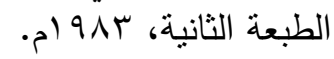
(T) من العقيدة إلىى الثورة د: حسن حنفي: (ONN/T). 


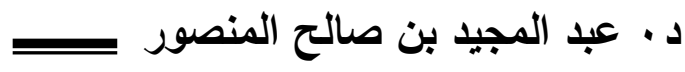

العبادة، وما يستحقه من الأسماء الحُسنى والصفات العُلى، فإن الإيمان ببقية الأركان لن يكون أحسن حالًا، ولا أقل ضلالًً، فقيما يتعلق بالإيمان بالملائكة: يُنكرون وجود هذا النوع من المخلوقات غير المحسوسة من حيثُ الأصل، ومنهم مَنْ يصفهم بما لا يليق بهم من التَّكم والسُّخرية، وهذا كثير في إنتاج الثُّعراء والأُدباء المنتمين لهذا الفكر ، وهو ما يَنم عن عدم الإيمان بهم ('). وأمَّا فيما يتعلق بالإيمان بالكتب: فإن الخِطاب الإلحادي يُنكر حقيقتها، ويُنكر وجود اتصال بين الله والأنبياء، فأنكروا الوحي وأنكروا الملائكة، والمحصلة: لابد من إنكار أن يكون ثمة كتب أنزلها الله إلى رسله، ومن أنكر وجود الله فمن باب أولى أن يُنكر الكُتب السَّماوية، ومَنْ أقر منهم بوجود الله أَنكر الوحي واعتبره مجرد خيال (r). وأما موقفهم من الإيمان بالرسل: فلا يبعد عن موقفهم من الإيمان بالكُنب، وانحرافهم الفكري في ذلك يظهر بجحد بعضهم الصريح بفكرة النبوة، ومِنْ ثم الكفر بجميع الأنبياء، لكونه بدون نبي، وأن ما يقع للأنبياء إنَّما هو مجرد خيال يتساوى لهري فيه البشر ممن يتوافر لهم قدرات خاصة، فليست النبوة هبة إلهية ولا اصطفاء ربانيًا، وأنّ الوحي لم ولن ينقطع؛ لأنه تعبير عن الطبيعة الإنسانية، وعليه: فالنُّبوة دائمة، ويمتد خطابهم إلى السخرية والانتقاص من مقام النبوة إلى إنكار العصمة (r) (ن)

وأمَّا موقفهم من الإيمان باليوم الآخر: فهو لا يخرج عن موقفهم من بقية

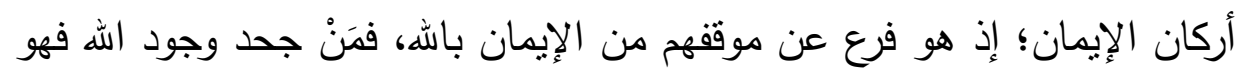
ولا بد مُنكر للبعث والحياة الآخرة، وفريق آخر : أثبت المعاد في الجملة لكن وفِق

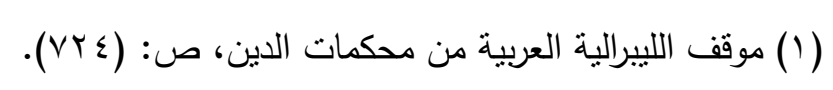

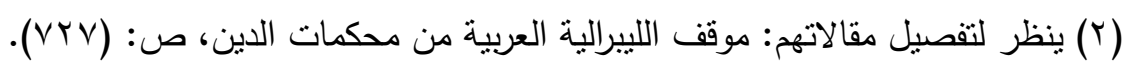

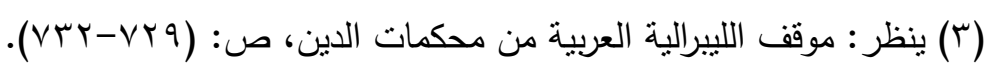


صفة تأويلية وتحريفية تُخالف ما عليه المسلمون، وتتتكب دلالات الكتاب والسئَّة دون دليل أو برهان، وهذا الصِّنف هو أثندها ضررًا؛ لأنهم يتلبسون بالدِّين، ويستخدمون آلته في محاولة هدمه وتخريبه، تحت مسميات التَّحرر الفِكري، والمسايرة للعصر ، والنظرة التتويرية للنّصوص، والتجديد للفهم وتجاوز العقليات الجامدة والتَّفسيرات السَّلفية الثَّابتة، وتقريب الإسلام لروح العصر ... ('). ولم يكن الركن السادس وهو الإيمان بالقدر بمعزل عما سبقه من أركان،

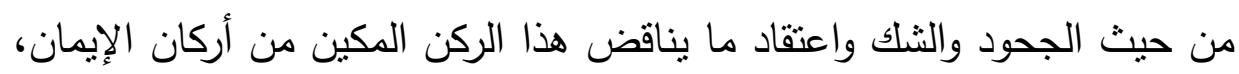
فإن مَنْ أنكر ربوبية الله أنكر قدره، ومَن جحد أسماء الله وصفاته جَحد علمه ومشيئته وقدرته، ولذا فقد تردد كثيرًا في الخِطاب الإلحادي الثناء على مذهب المعتزلة لكونه المذهب الذي أنكر القدر، وجعل فعل الإنسان مخلوقًا له، وهو المذهب الذي اشتخ نكير المسلمين له من لدن أصحاب النبي عليهوسلم ومن جاء بعده من أعلام الأمة وأئمتها (r). الفرع الثالث: موقف الملحدين من تحكيم الثريعة، وأصول الدين

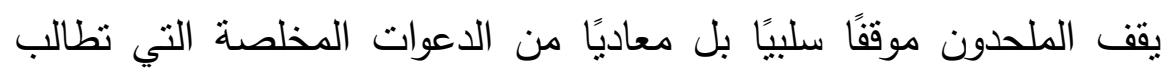
بتطبيق الثربعة الإسلامية في بلاد المسلمين حتى في البلاد التي لا تعترف بالديمقراطية أو تمارسها صوريًا؛ لذا بعضهم يقول: إن الثريعة ليست ذات ألصدل أصل

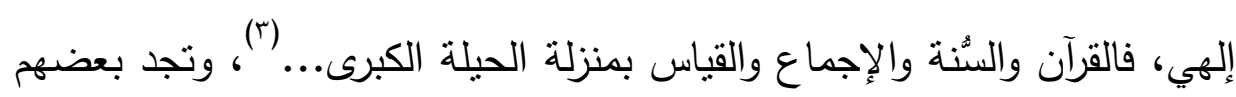
يدعو إلى العلمانية بمفهومها الثامل، أو يدعو إلى الديمقراطية التى هى حكم

(1) موقف اللييرالية العربية من محكمات الدين، ص: (VTr)، وفيه سرد المؤلف بعض أقاويلهم التي يقف لها شعر الرأس.

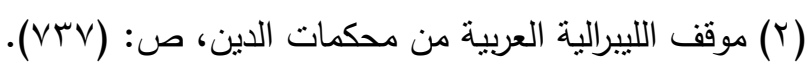

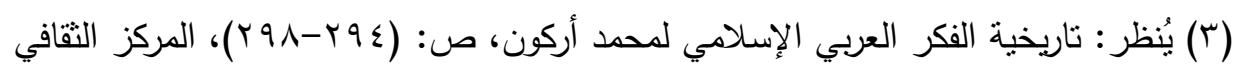

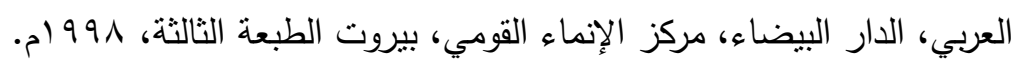




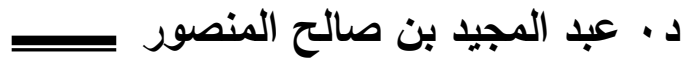

الثعب بالثعب كبديل عن تحكيم الثريعة، وأن العلمانية ثابت مركزي من ثوابت

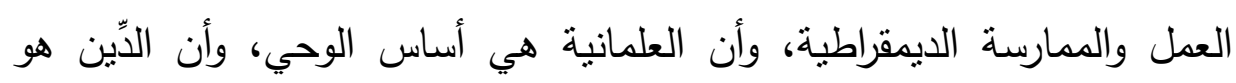
سبب تخلف المجتمعات العربية.' (1). هذه بعض انحرافاتهم الفكرية الثيطانية، وآرائهم الفاسدة التي تهدم أمن أهم

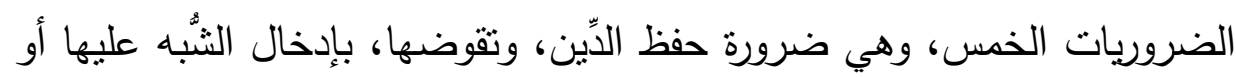
تأويلها أو إنكارها، ولم ينرك المنهج الإلحادي أصلًا أو فرعًا من الدِّين إلا وقد

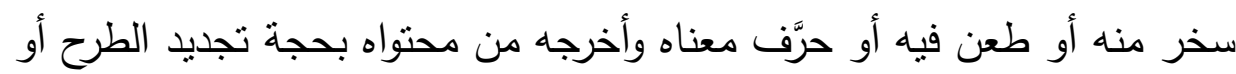
عدم الملاءمة مع العصر، ولا أعظم جرمًا من ذلك؛ ولو ترك الأمر لهؤلاء

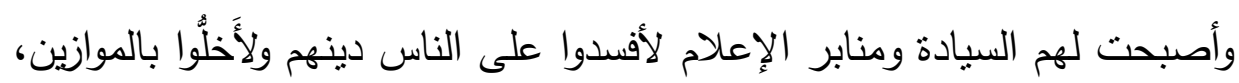
وأفقدوا المعايير التي يُعرف بها الحق من الباطل والصيُواب من الخطأ، والهُّى من الضلال، والله المستعان.

(1) يُنظر : جذور الليبرالية العربية، ص: (ON-OV)، موقف الليبرالية العربية من محكمات

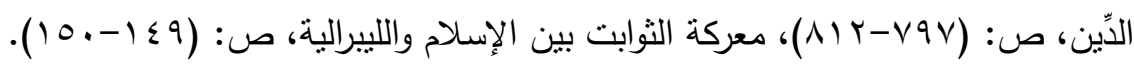




\section{المبحث الثاني:}

\section{أثر جريمة الإلحاد على حفظ ضرورة النفس}

سبق أنَّ حفظ ضرورة النَّس تكون بمراعاة حق النَّس في الحياة والسَّلامة والكرامة

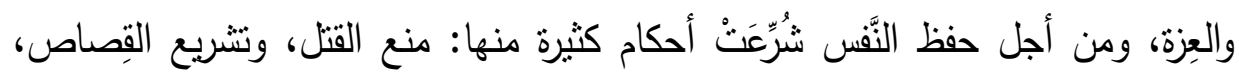

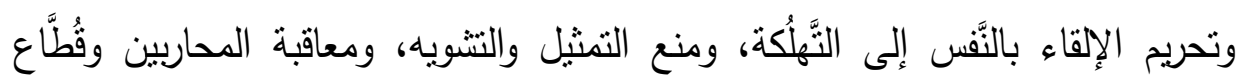

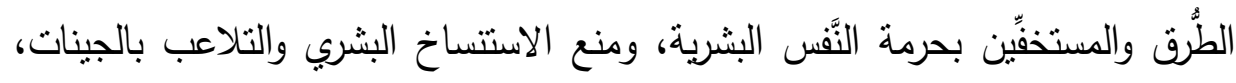
والمتاجرة بالأعضاء والتشريح لغير ضرورة معتبرة، وحرق أجساد الموتى، كما أمر بتناول ما تقوم به النَّس من أكل وشرب وعلاج.

وفي النَّظر الأول المبلئي البسيط إلى منهج الإلحاد وخطابات الملحدين قد لا

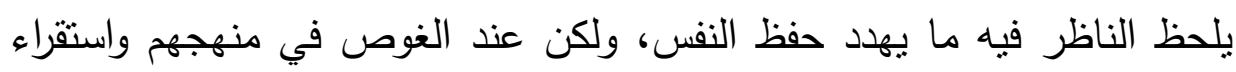
خطاباتهم نجد فيه ما يهنك حفظ النفس من عدة مداخل واقعية ينتبه لها البصير

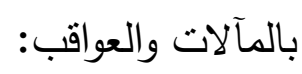

الأول: أنَّ موقف الملحدين من تحكيم الثريعة الإسلامية هو الرفض

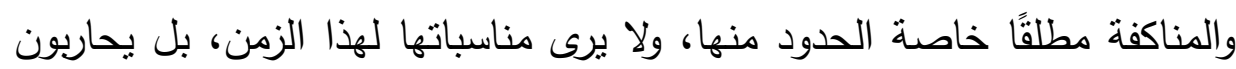

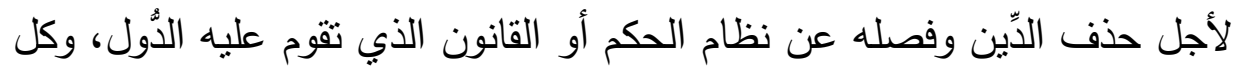

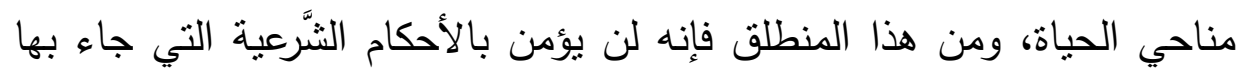

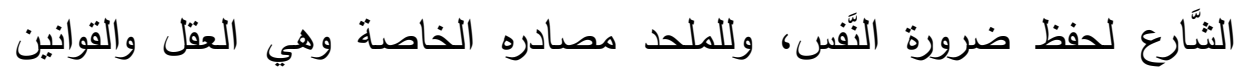
الوضعية، وهي لن تحقق حفظ أمن النَّس كما أراده خالق البشرية، ولكن كما وضعها العقل البشري الناقص.

الثاني: أنَّ الفِكر الإحلحي المُجرم يُعارض تطبيق الحدود الثُّرعية المقدرة مطلقًا، بما في ذلك القتل العدد والقِصاص متذرعًا ببعض الثنبّه والإسقاطات 


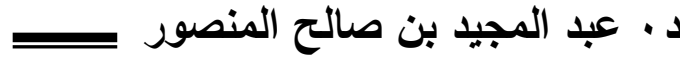

الخاطئة منها: أن مصدر تقدير الحدود وهو القرآن والسُّنة لا يصح أن يتخذ

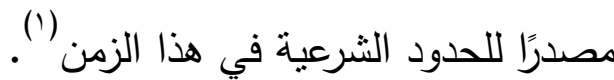
الثالث: أن إسقاط حق القتل العمد والقصاص والاعتياض عنه بالسجن المؤبد ونحوه كما يُطالب الملحدون بكل اتجاهاتهم؛ يؤول إلى تهديد حفظ ضرورة الأنفس في المجتمع من جهة تهاون المجرمين بها إذا علم المجرم أنه لن يقتل،

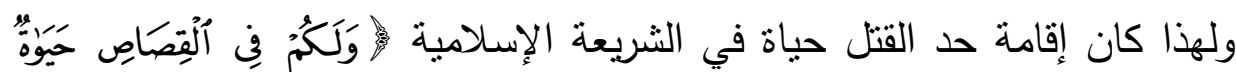

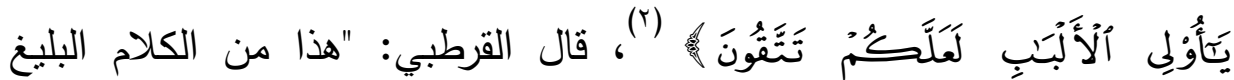
الوجيز ومعناه: لا يقتل بعضكم بعضيًا...والمعنى: أن القِصاص إذا أُقيم وتحقق الحكم فيه ازدجر مَن يريد قتل آخر، مخافة أن يُقتص منه فحييا بذلك معًا، وكانت العرب إذا قتل الرجل الآخر حمي قبيلاهما وتقاتلوا، وكان ذلك داعيًا إلى قتل العدد الكثير، فلمَّا شرع الهه القِصاص قنع الكل به وتركوا الاقتنال، فلهم في ذلك حياة"(") وقال ابن كثير : "يقول تعالى: وفي شرع القِصاص لكم وهو قتل القاتل حكمة عظيمة وهي بقاء المُهَج وصونها؛ لأنه إذا عَلمِ القاتل أنه يُقتل؛ انكفَّ عن صنيعه فكان في ذللك حياة للنفوس، وفي الكتب المتقدمة: القتل أنفى للقتل، فجاءت هذه العبارة في القرآن أفصح وأبلخ وأوجز حَيَةِّة هُ، قال أبو العالية: جعل الله القِصاص حياة، فكم من رجل يُريد أن يَقتل

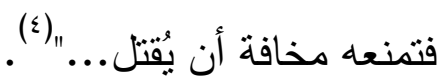

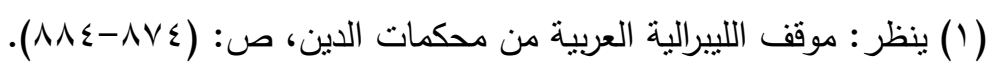

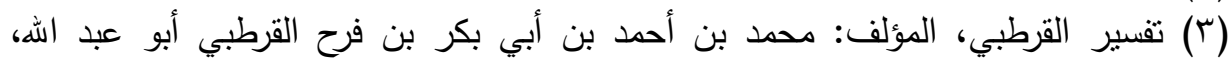

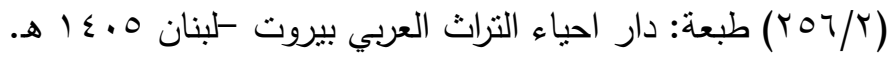

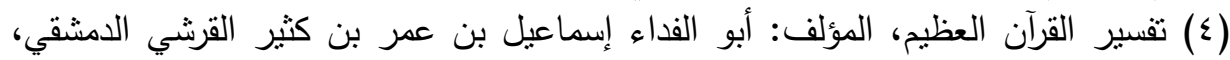

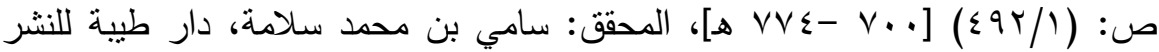

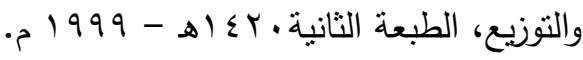




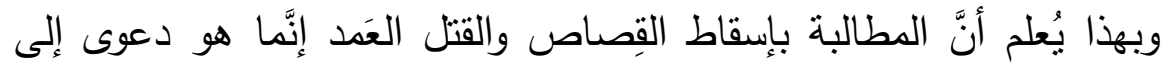

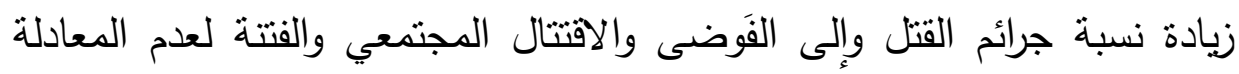

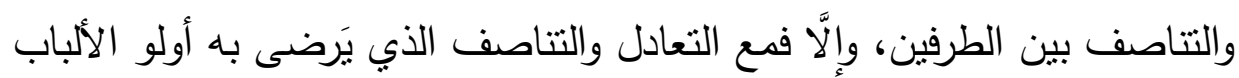
لا تبقى فنتة.

الرابع: أنَّ من الآثار الخطيرة التي قد يورثها الإحاد الانتحار بسبب الحيرة

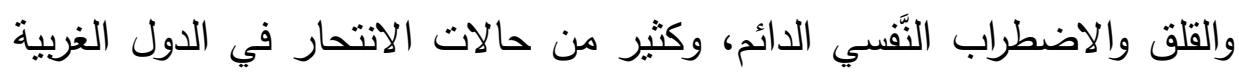

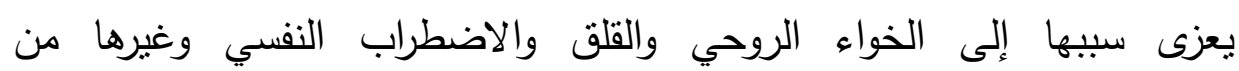

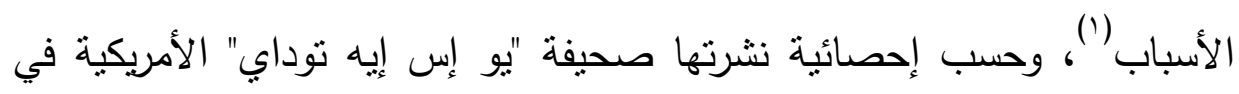

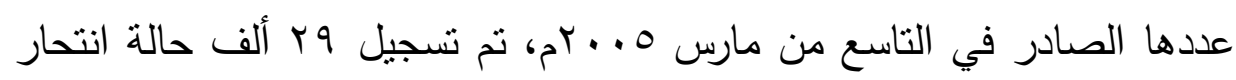

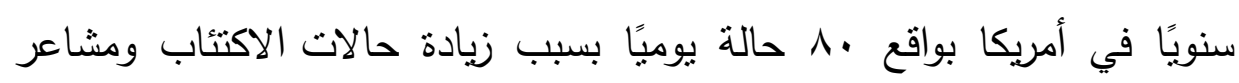

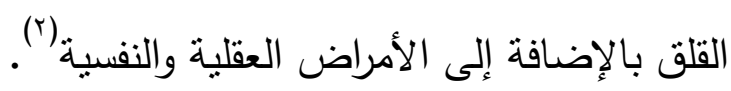

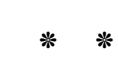

(1) ينظر مقال: الانتحار في الغرب، ظاهرة تستحق التأمل، موقع لها أون لاين. https://cutt.us/vIZuN https://cutt.us/Bmv6P صحيفة اليوم الإلكترونية: (r) 


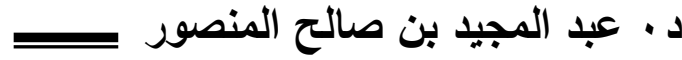

\section{المبحث الثالث:}

\section{أثز جريمة الإلحاد على حفظ ضرورة العقل}

سبق البيان أن الإسلام اهتم بالعقل من عدة جوانب فجعله شرطًا في التكليف وأمر بالتفكر والتدبر ، ومنع ما يعيقه ويعطله، وذللك كمنع المُسكرات والمُخدرات والمُفترات، وكل ما يُغيِّب العقل عن دوره في التفكير والتَّبرِ، وجعل له حدودًا وقيودًا لا يتعداها ولا يتجاوزها؛ وذلك لأن إطلاق العقل وتحريره بشكل مُطلق يؤدي لا محالة إلى مفاسد لا تقل خطورة عن مفاسد تعطيله وتحجيم دوره؛ فحفظ العقل مصان بالوسطية الإسلامية المعهودة بإثبات دوره ومكانته وضبطه بقيود معتبرة وضوابط معلومة، ولأجل ذلك نجد الشريعة الإسلامية تحارب الإنحرافات الفكرية الضالة الغالية أو الجافية، وتمنع من التسويق لها أو السَّماح بترويجها كالزندقة والإلحاد والغُلو والتطرف، كل ذلك حماية لأمن العقل بالإضافة لضرورة الدِّين.

ولمَّا اطلعنا على خطاب الملحدين بكل اتجاهاتهم وجدنا لمنهجهم أثز سلبي على حفظ هذه الضرورة، ويُشكل خطرًا كبيرًا على أمن العقل من عدة جوانب: الأول: أن الملحدين يدعون إلى تمرد العقل وتحرره من سلطة اللِّين والمرجعية الثرعية إلى المرجعية العقلية، بل وتقديم العقل على النَّص الثرعي، وجعل السلطان المطلق للعقل، بحيث لا يكون هناك سلطان على العقل للعقل إلآّا وحده، وفتح الباب للعقل ليمارس حرية تأويل النصوص، واعتبار أن العقل المجرد هو المصدر الموثوق في تحصيل المعرفة بأنواعها دون غيره، خصوصًا في المسائل الدِّنية العقدية منها والتشريعية، وهؤلاء على طبقات منهم المقارب ومنهم الغلاة، ويجمعه التقديس للعقل ورفعه عن مكانته الحقيقية، وإعطاؤه أكبر من حجمه، وهذا خلل فكري ظاهر ومنهج باطل ('). ( (1) يُنر للوقوف على خطاباتهم مفصلة: موقف الليبرالية العربية من محكمات الدين ص: . (Or $\leqslant-\varepsilon T V)$ 
والسماح لهذا الفِكر بالتسويق والرواج يعارض مقصد الثربعة بحفظ ضرورة

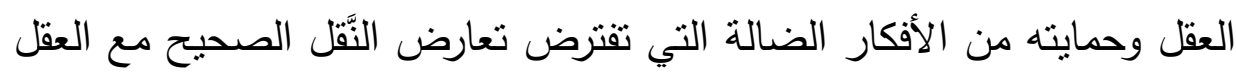
الصريح.

الثاني: دَرَج دعاة الإحاد على التهوين من شأن الخمور والمُسكرات

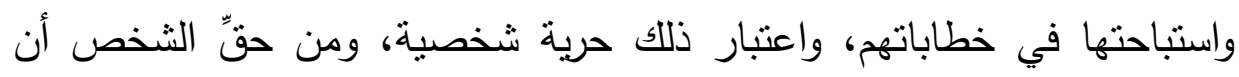
يتعاطى هذه الأمور وإثاعة منل هذه الأطروحات في المجتمع (') واله المستعان. ( (1) يُظر خطاباتهم في ذلك: موقف اللييرالية العربية من محكمات الدين، ص: (^乏؟). 
בب د · عبد المجيد بن صالح المنصور عـ

المبحث الرابع:

أثر جريمة الإلحاد على حفظ ضرورة النَّل

والِعرض وض والنَّبب

سبق أنَّ حفظ النَّل معناه: التتاسل والتوالد لإعمار الكَون، وحفظ النَّسب معناه: القيام بالتناسل المشروع عن طريق العلاقة الزوجية الثَّرعية، وحِظ العِرض معناه: صيانة الكَرامة والعِفَّة والثَّرَف، والمعاني الثناثنة المذكورة "النَّسل والنَّسب واللعِرض" تُعد المقصد الثَّرعي الكُلي الرابع الذي أقره الإسـام في ولي نصوصه وأحكامه، وأثبتهه وجذَّرَه من خلال تشريعات عدة نَذكر منها، الحث على الِّ الزواج، وتخفيف أعبائه وتيسير مصروفاته، ومنع الزنا، وسد منافذه وذرائعه،

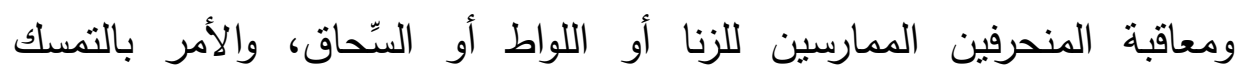
بالأخلاق الفاضلة والقيم العليا، والنَّهي عن الرذائل والفواحش والمُنكرات، والحثِّ لِّن على السِّز والعِفة والتحوط والحياء. وبإمعان النَّظر إلىى الإحاد وجدنا أنه يَنحر الأمن في ضرورة العِرض والنَّسل والنَّبب من الوريد إلى الوريد، ولا بدع حياءً ولا عِفة ولا سِترًا إلَّاّ هَتَكه، ويتضِح ذلك من عدة جوانب:

الأول: أنَّ مِن طبائع الإحاد اتباع الثهوات والانطلاق في الإباحية، فالمُلحد لا يحافظ على عِرض أحد، ولا على حُرمه، إلَّا أنْ يعجز عن الوصول إلى شيء من

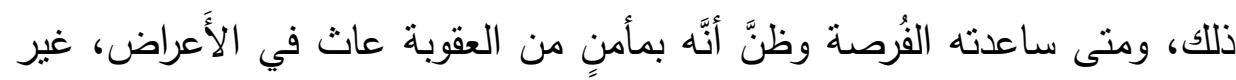
متحرج من انتهاك حرماتها، وقد يقع انتهاك الأعراض ونحوها من غير الملحد بدافع

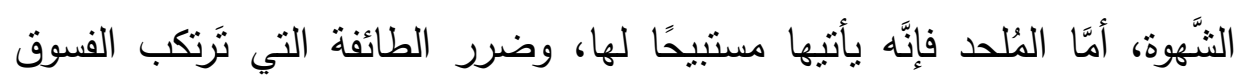
مستبيحة له أشثد من ضرر مَن يفعله معنقدًا أنه يأتي أمرًا محرمًا '(').

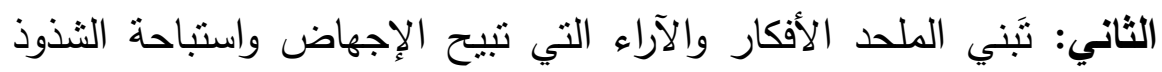
( (1) يُنظر : الإلحاد أسبابه وطبائعه ومفاسده وأسباب ظهوره، ص: (·). 
الجنسي، وصياغة نظرية نسوية لتحقيق المساواة التماتلية بين الجنسين عن طريق الإد

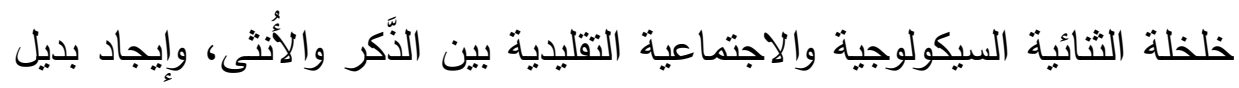

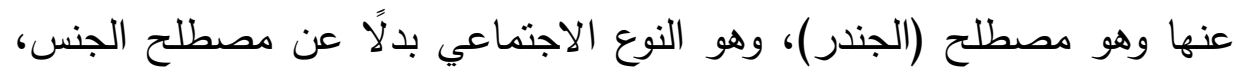

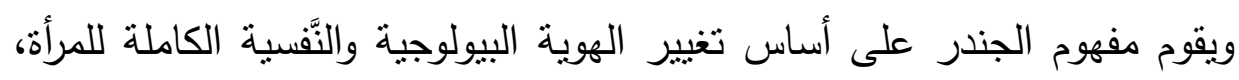

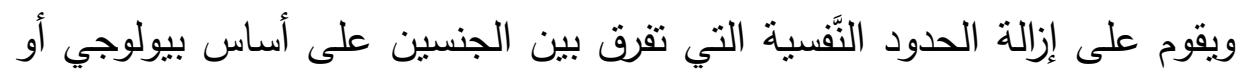

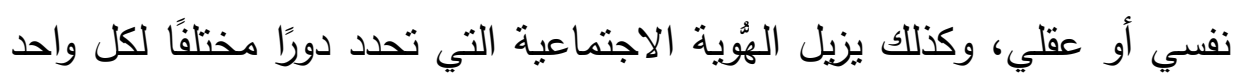
من الجنسين في الحياة، وتمايزه عن الجنس الآخر (').

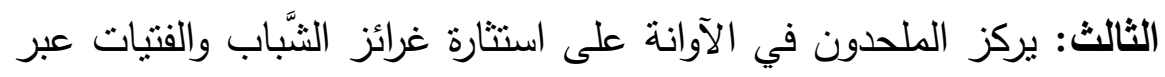

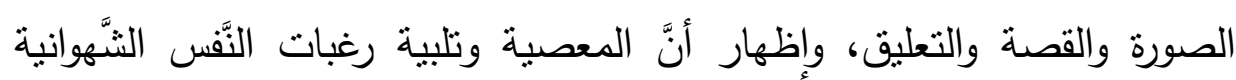
المُحرمة تجلب لهم السَّعادة والرَّاحة النَّفسية (r).

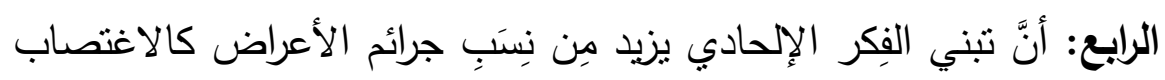

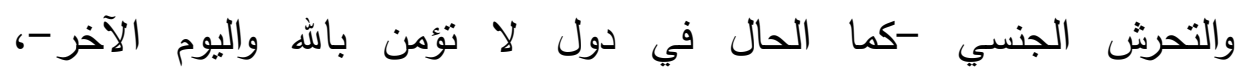

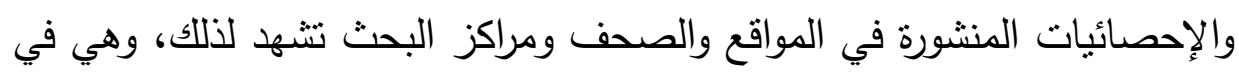
متتاول اليد لمن أراد الوصول إليها.

(1) يُنظر في موقف الملحدين من قضايا المرأة: معركة الثوابت بين الإنلام والليبرالية

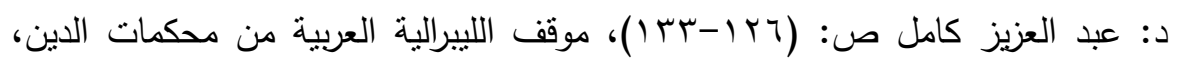

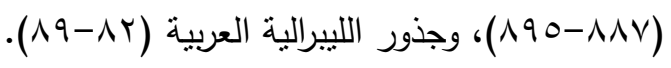

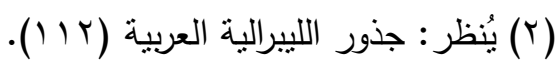

$$
\begin{aligned}
& -1 \text { r人- }
\end{aligned}
$$




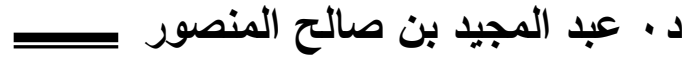

المبحث الخامس:

\section{أثر جريمة الإلحاد على حفظ ضرورة المال}

سبق أن حفظ المال معناه: إنماؤه وإثراؤه وصيانته من التلف والضياع

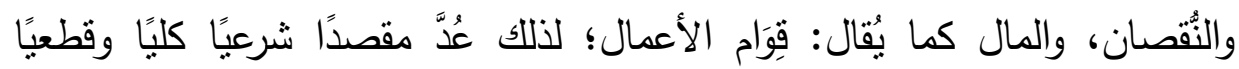

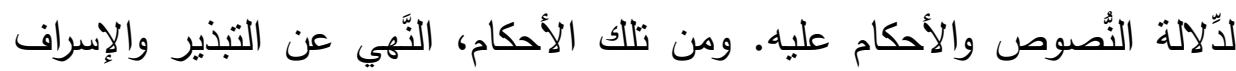

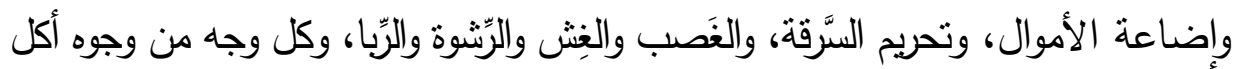

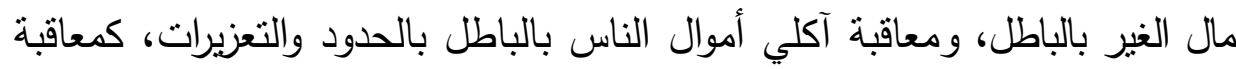

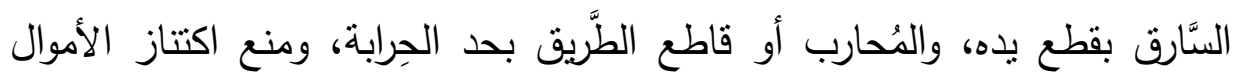
وتكديسها كي لا يُسهم في تعطيل ترويجها والانتفاع بها والاستفادة منها.

ويإمعان النظر إلى فكر الإلحاد وجلنا أنه يُقِّوض الأمن في ضرورة حفظ المال، ويتضح ذلك من عدة جوانب:

الأول: أنَّه لا يؤمن بحرمة الربا، وأنَّ مِن شأنه تحريك العجلة الاقتصادية إلى

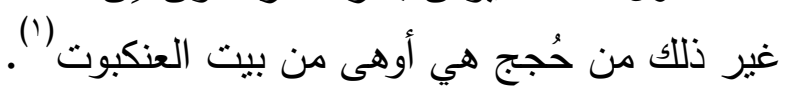

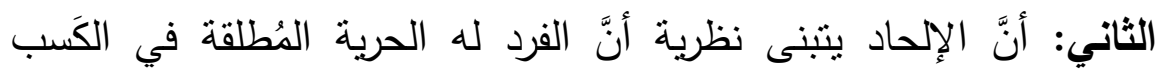
والإِنفاق والاستهلاك ونوع التجارة التي يتعاطاها، وحرية العمل والتعاقد وحرية

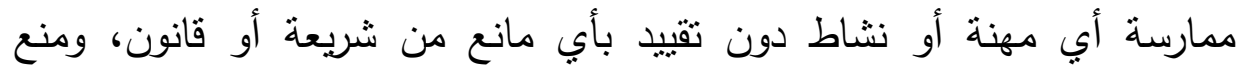

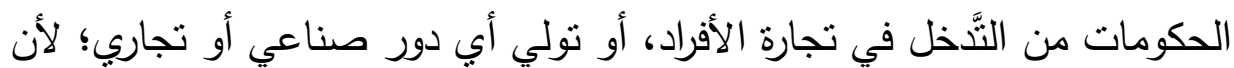
مصلحة الفرد والجماعة تتضرر بتدخل الدَّولة في الاقتصاد، ومبدؤهم في النّاية

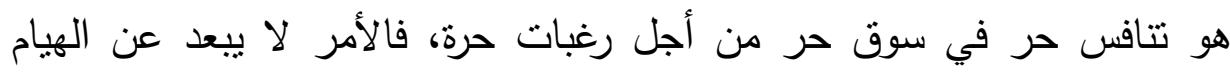

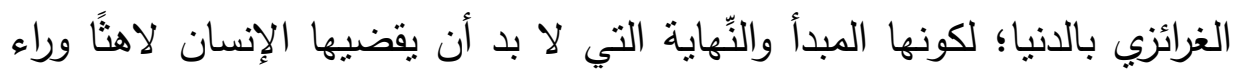

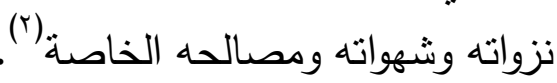

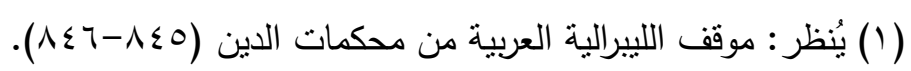

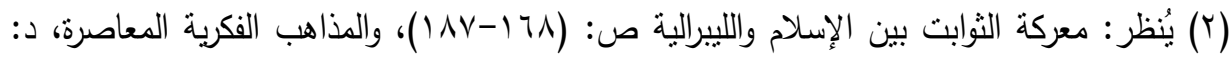

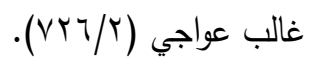




\section{أثر فكر الإلحاد}

الثالث: أنَّ القبول بالنَّرية الإلحادية الاقتصادية السابقة يؤثر سلبًا على

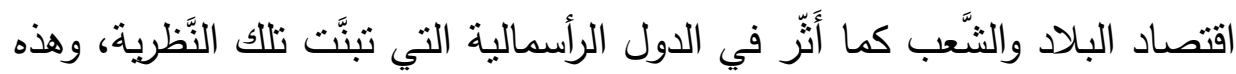

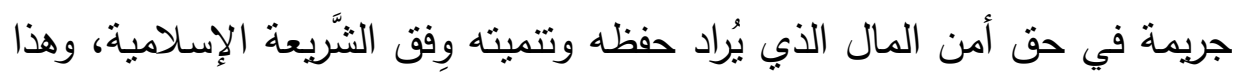
ما التزمه دستور هذه البلاد الذي جعل الكتاب والسُّنَّة حاكمين على كل جوانب

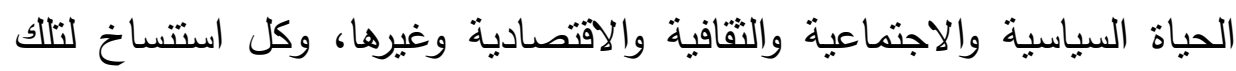

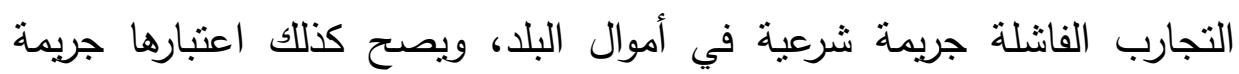
نظامية، وقد نصَّت المادة (VI) من دستور هذه البلاد على أن: (الملكية ورأس

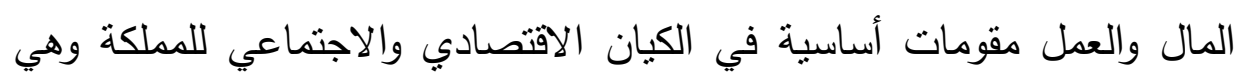

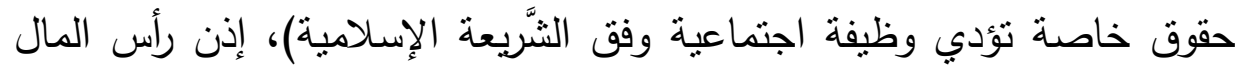

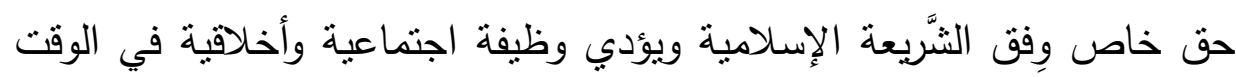

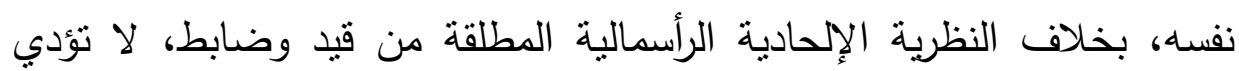

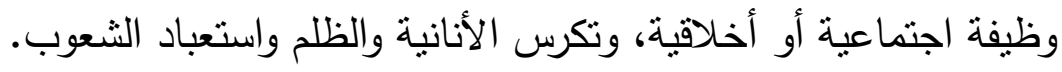


د. • عبد المجيد بن صالح المنصور عـ

\section{الخاتمــة}

الحمد الله أولًا وآخرًا وظاهرًا وياطنًا ... ويعد:

فهذه خاتمة تضم خلاصة معتصرة للبحث، ونتائجه المنثورة بين دفتيه؛

لأضع البحث أمام كل مستفيد منها على طرف الثمام '.

فأقول في هذا المضمار : أهم نتائج هذا البحث:

1. أنَّ الإلحاد في الاصطلاح المعاصر هو: مذهب فلسفي يقوم على فكرة عدمية

أساسها إنكار وجود الله الخالق سبحانه، فيدّعي الملحدون بأنَّ الكون وُجِدَ بـلا

خالق، وأن المادة أزلية أبدية، وهي الخالق والمخلوق في نفس الوقت.

r. أنَّ الجريمة في الاصطلاح لها معنيان عام وخاص: والعام: هو معصية الله

ومعصية رسوله عليقوسلمه، والخاص هو: محظورات شرعية زجر الله عنها بحد

أو تعزير

r. أنَّ الضروريات هي التي لا بد منها في قيام مصالح الأِّين والدّنيا، بحيث إذا فقدت لم تجر مصالح الدنيا على استقامة، بل على فساد وتهارج وفوت حياة، وفي الأخرى فوت النجاة والنعيم، والرجوع بالخسران.

؟. أن الضروريات الخمس، أو الأصول الخمسة، أو الكليات الخمس، هي

بالترتيب: الدِّين، والنَّفس، والنَّسل، والعقل، والمال، ومنهم مَنْ يُرتب العقل قبل النَّسل، وأضاف بعض العلماء كالطوفي وابن السُّكي وغيرهما إلى الخمسة ساسيًا وهو ضرورة حفظ العِرض. - ل

(1) هذا مَتَل تقوله العرب للثيء الذي لا يُعسر نتاوله، وذلك أن الثمام لا بطول فيشق تتاوله

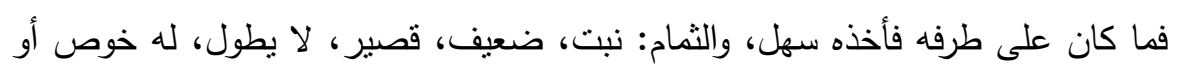

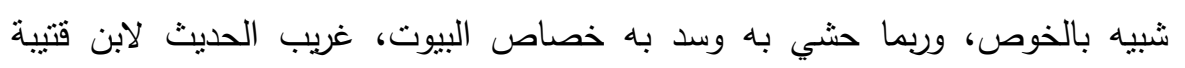

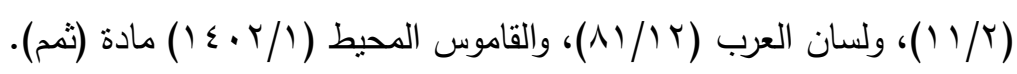


أثز فكر الإلحاد

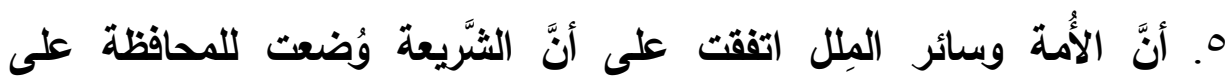

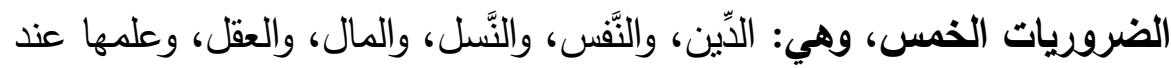

$$
\text { الأمة كالضروري. }
$$

T. أنَّ الضروريات سميت بنلك؛ لأنَها مصالح لا يمكن الاستغناء عنها، ولا نتظظم الحياة

من دونها.

V. أنَّ المراد بحفظ الضروريات الخمس: تحقيق الأمن لها، وإيجادها وتحقيقها

$$
\text { وتحقيق مقاصدها، وصيانتها من الاعنداء عليها. }
$$

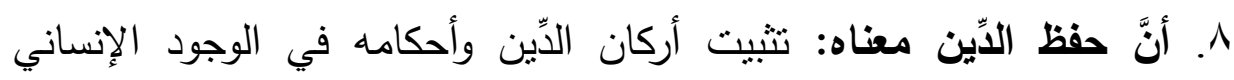

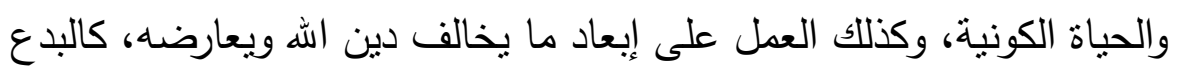

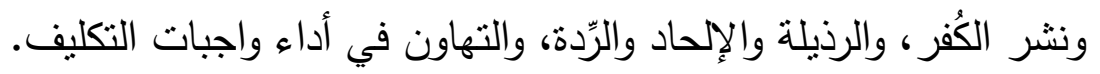

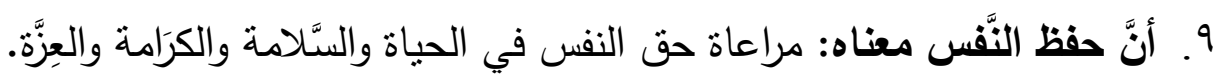

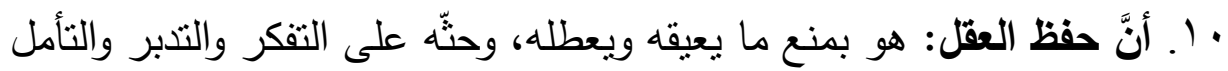

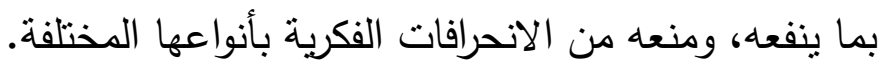

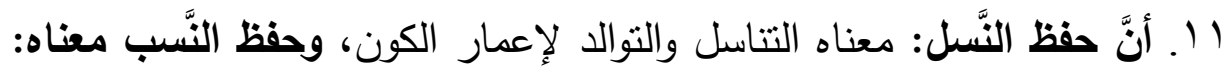

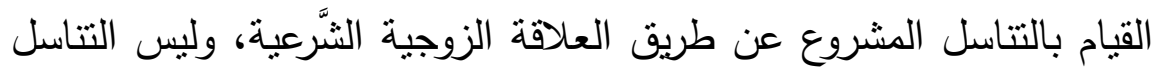

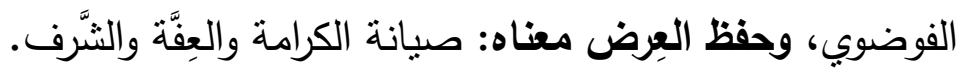

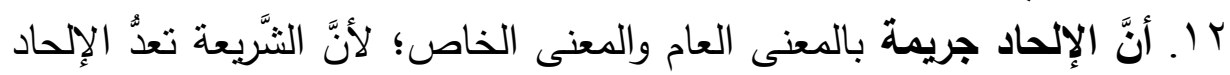

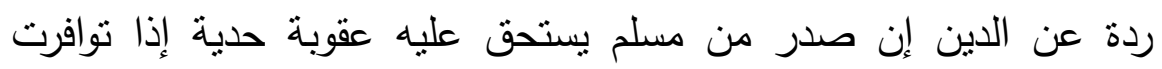

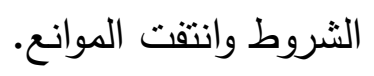

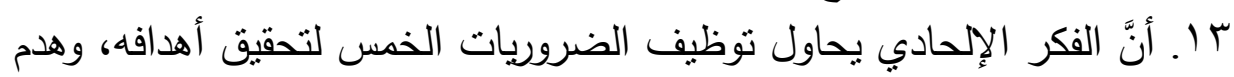

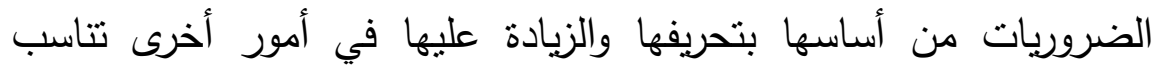

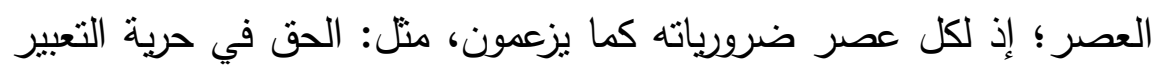
والتقكير وحرية الانتماء الديني والسياسي.

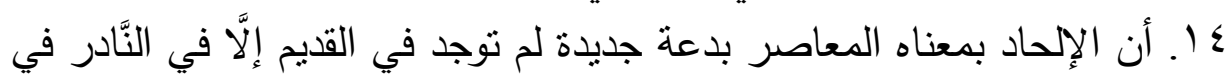

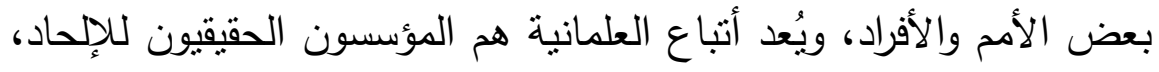
ومن هؤلاء: أتباع الثيوعية والوجودية والداروينية. 


\section{د. • عبد المجيد بن صالح المنصور عـ}

1. أنَّنا لما أجلنا النظر في الإلحاد وكلام الملحدين تبيّن لنا بما لا يدع مجالًا للثك أنه يهدم ضرورة أمن الدِّين، ويقوّضض أركانه وأحكامه، ويُشكل خطرًا كبيرًا على عقيدة المسلمين. 7 1. أنَّ مواد دستور المملكة العربية السعودية مفصلية وواضحة في دِلالاتها ومضامينها ومناهضتها لكل الانحرافات الفكرية بما في ذلك فكر الإحاد بكل جذوره واتجاهاته. V V أنَّ الإلحاد يهدد أمن ضرورة حفظ النَّفس من جهة أنهم لا يؤمنون بتحكيم الثريعة الإسلامية وما جاء فيها من طُرق حفظ النَّفس، ويستقون تلك الطرق من القوانين الوضعية، وأنَّه يعارض تطبيق الحدود الثَّرعية المقدرة مطلقًا بما في ذلك القتل العدد والقِصَاص، ويعتاض عنها بالسجن المؤبد ونحوه مما لا يحقق الردع ويُوقف آلة القتل، بل يؤدي إلى زيادة نسبة جرائم القتل وإلى الفوضى والاقتتال المجتمعي والفتتة لعدم المعادلة والتتاصف بين الطرفين. 1) أنَّ جريمة الإلحاد تشكل خطرًا كبيرًا على أمن عقول المجتمع من جهة أنَّه يدعو إلى تمرد العقل، وتحرره من سلطة الدّيّن والمرجعية الثَّرعية إلى المرجعية العقلية، بل وتقديم العقل على النَّص الثَّرعي، ومن جهة تهوينهم مِن شأن الخمور والمُسكرات في خطاباتهم واستحلالهم شربها وأكلها تحت ذربعة الحرية

$$
\text { الثخصية. }
$$

9 1. أنَّ فِكر الإحلحاد جريمة في حق حفظ ضرورة النَّسل والعِرض والنَّسب، وينتيَّن ذلك من خلال معرفة طبائعه، والوقوف على خطابات رموزه، والقضايا التي

$$
\text { ينافحون لأجلها. }
$$

•r. أنَّ كل مَنْ يدعو إلى الإحاد صراحة أو ضمنًا إنَّما يريد نشر هذه الجرائم في

$$
\text { بلاد المسلمين صراحة أو باللازم أو التضمن، فوجب الحذر منهم. }
$$

اY. أنَّ جريمة الإلحاد ثُقِِّضض الأمن في ضرورة حفظ المال بإباحته الربا الذي الني

يُذهب بركة المال، وتبنِّهه النَّظرية الاقتصادية المادية غير الثرعية. 
r r. تُوصى الدراسة المؤسسات التظظيمية بالالتفات إلى هذا الخطر الفكري الكبير

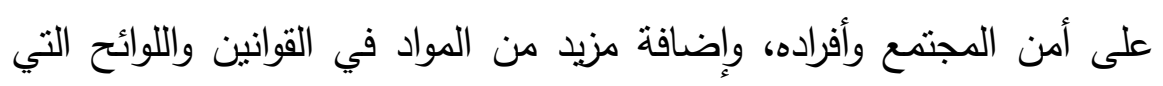
تصرح بتجريم هذا الفكر والدعوة إليه ومعاقبته. rr. يُوصى البحث أيضا بتعليل بعض المواد التتظيمية المتعلقة بالقضاء بما بيسح

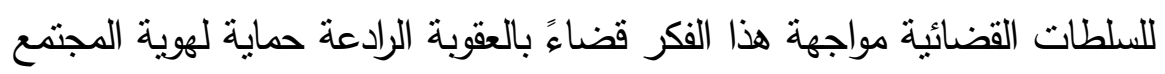
من التنيس والتغيير. צY. كما يُوصى بتوجيه وسائل الإعلام التقليدية والحديثة رسميًا لمواجهة هذا الفكر المنحرف الذي يهدد الجيل الجديد ويُغير هويته الإسلامية، ودعم

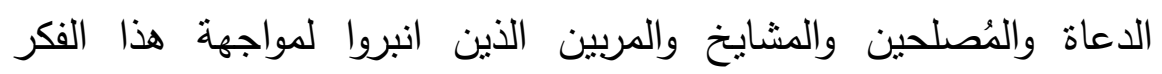

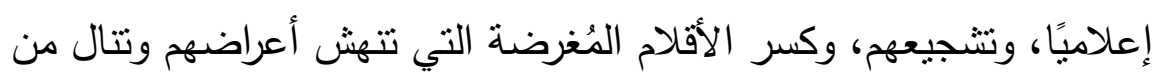
دينهم، وتتشكك في مصداقيتهم، وتطعن في وطنيتهم وغيرتهم على البلاد.

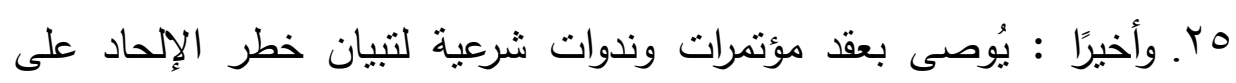

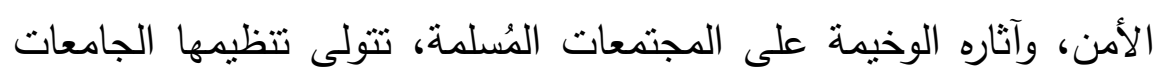

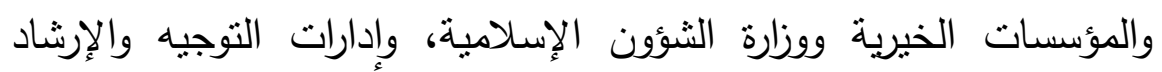
والتوعية الدِّينية والثؤون الدِّينية في كل قطاعات الدَّولة لحماية أمن الدّيّن

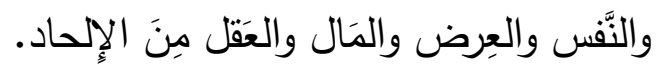


בد د عبد المجيد بن صالح المنصور عـ

\section{المراجع والمصادر}

1 -إبراهيم، د: بسيوني، التلبس بالجربمة وأثثه في الفقه الإسلامي والقانون

الوضعي، دار الجامعة الجديدة، الإسكندرية.

r-ابن الأثير، أبو السعادات المبارك بن محمد الجزري، النهاية في غريب الحديث

والأثر، تحقيق: طاهر أحمد الزاوي، محمود الطناجي، المكنبة العلمية، بيروت،

99 (1)

r-ابن النجار، تقي الدين أبو البقاء محمد بن أحمد بن عبد العزيز بن علي الفتوحي، شرح الكوكب المنير، تحقيق: محمد الزحيلي ونزيه حماد، مكتبة

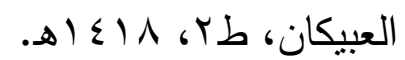

ع - ابن فارس، أبو الحسين أحمد بن فارس بن زكريا، معجم مقاييس اللغة، تحقيق:

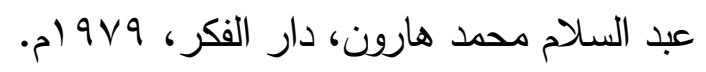

هـ ابن كثير، أبو الفداء إسماعيل بن عمر بن كثير القرشي الدمثقي، تقسير القرآن

العظيم، المحقق: سامي بن محمد سلامة، دار طيبة للنشر والتوزيع، ط. بع اهـ -

$$
\text { . }) 999
$$

7ـ ابن مفلح، محمد بن مفلح بن محمد بن مفرج، أبو عبد الله، شمس الدين المقدسي الرامينى ثم الصالحي الحنبلي، أصول الفقه، تحقيق: د: فهر بن بن بن بن بن

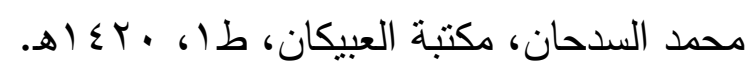

V- ابن منظور محمد بن مكرم الإفريقي المصري، لسان العرب، الناشر: دار

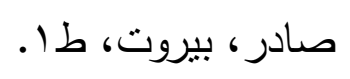

^- أركون، محمد، تاريخية الفكر العربي الإسلامي، المركز التقافي العربي، الدار

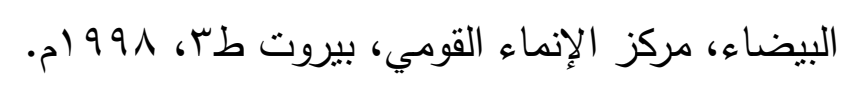

9 - حنفي، حسن، من العقيدة إلى الثورة، مكتبة مدبولي، القاهرة، بدون طبعة. • 1 - حوراني، ألبرت، الفكر العربي في عصر النهضة، نرجمه إلى العربية كريم

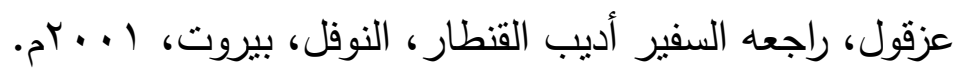


ا ( الخادمي، نور الدين بن مختار، علم المقاصد الثرعية، مكتبة العبيكان،

$$
\text { ط) }
$$

r ا -خلاّف، عبد الوهاب، علم أصول الفقه وخلاصة تاريخ التشربع، مطبعة

$$
\text { المدني 》المؤسسة السعودية بمصر « . }
$$

ץ ا - د: أبو زهرة، محمد، الجريمة والعقوبة في الفقه الإسلامي، دار الفكر

$$
\text { العربي، القاهرة، عبـ اله. }
$$

ع ا - د: البطوش، بسام، جذور الليبرالية العربية (الحالة المصرية)، دار كنوز

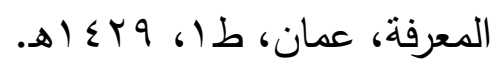

1 ـ د: الدميجي، صالح بن محمد، موقف الليبرالية في البلاد العربية من

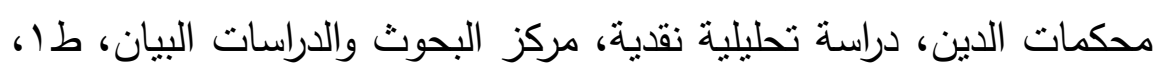

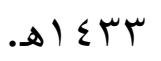

7 ا - د: العجلان، عبد الله بن سليمان، التشريع الجنائي الإسلامي، طا،

$$
\text { . } 1 \leqslant Y q
$$

IV د د بكر، علاء، الإسلام والليبرالية مواجهة صريحة، الناشر : مكتبة فياض،

$$
\text { المنصورة. }
$$

1 ا ـ د: حنفي، حسن، قضايا معاصرة في فكرنا المعاصر ، دار التتوير، بيروت، طب،

$$
\text { . } 9 \text { ) } 9 \wedge
$$

9 ( الريسوني، أحمد، الفكر المقاصدي، قواعده، وفوائده، دار الكلمة، طس،

$$
\text { . }
$$

• †- الريسوني، أحمد، محاضرات في مقاصد الثربعة، دار الكلمة، طع،

$$
\text { דب إهـ }
$$

ا Y - الريسوني، أحمد، مدخل إلى مقاصد الثربعة، دار الكلمة، طس، هبء أهـ

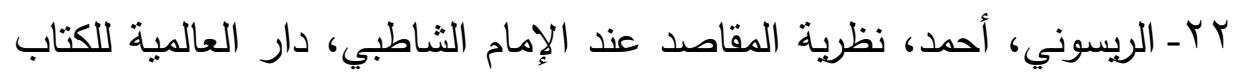

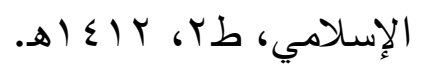




\section{د. • عبد المجيد بن صالح المنصور عـ}

بr - الزركثي بدر الدين، البحر المحيط في أصول الفقه، تحقيق: محمد محمد

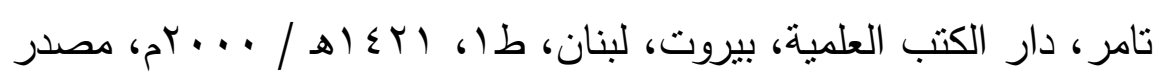

الكتاب: موقع مكتبة المدينة الرقمية.

ـ اـ الزركثي، أبو عبد الله بدر الدين محمد بن عبد الله بن بهادر الثافعي،

تشنيف المسامع بجمع الجوامع، تحقيق: د: سيد عبد العزيز، د: عبد الله ربيع، الناشر: مكتبة قرطبة للبحث العلمي وإحياء التراث، توزيع المكتبة

المكية.

0 - الثاطبي، إبراهيم بن موسى بن محمد اللخمي، الموافقات، تحقيق: مشهور

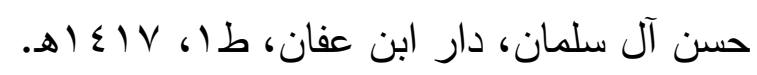
جr- الثنقيطي، محمد الأمين بن المختار الشنقيطي، علاج القرآن للجريمة،

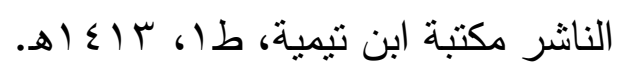
rV ا الثوكاني، محمد بن علي بن محمد، إرشاد الفحول إلى تحقيق الحق من علم الأصول، تحقيق: الثيخ أحمد عزو عناية، الناشر: دار الكتاب العربي،

$$
\text { ط ط) }
$$

^r - الطبري، محمد بن جربر ، جامع البيان في تأويل القرآن، تحقيق: أحمد شاكر،

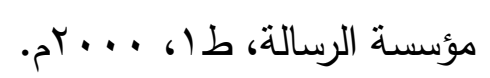

وץـ الطوفي، سليمان بن عبد القوي بن الكريم الطوفي الصرصري، أبو الربيع، نجم

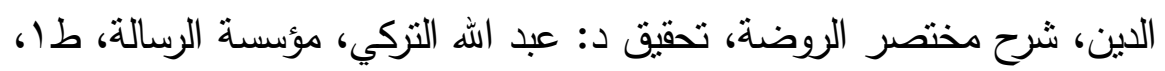

$$
\text { هـ } \varepsilon \cdot V
$$

• rـ العراقي، ولي الدين أبي زرعة أحمد بن عبد الرحيم، الغيث الهامع شرح جمع

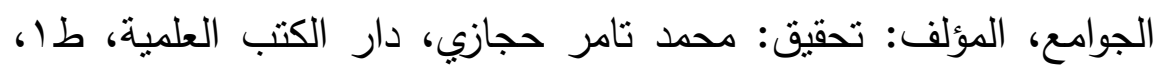

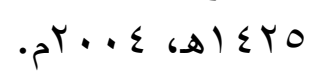

اس- عواجي، د. غالب بن علي، المذاهب الفكرية المعاصرة ودورها في

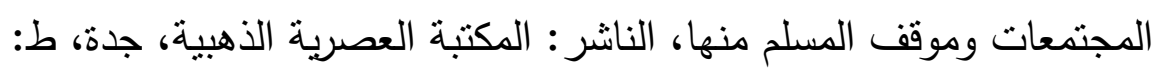

$$
\cdot{ }^{2}+\cdot T
$$


rr- عودة، د: عبد القادر، التشريع الجنائي الإسلامي مقارنا بالقانون الوضعي،

$$
\text { دار الكتاب العربي، بيروت. }
$$

سبـ الغزالي، أبو حامد محمد بن محمد، المستصفى في الأصول، تحقيق: محمد الثافي، دار الكتب العلمية، بيروت لبنان، ط ا، باء (اهـ.

ع זـ الفيومي، أحمد بن محمد بن علي المقري، المصباح المنير، تحقيق: يوسف

الشيخ محمد، المكنبة العصرية.

هـ- القاضي أبو بعلى، محمد بن الحسين بن محمد بن خلف ابن الفراء، الأحكام السلطانية، تحقيق: محمد حامد الفقي، دار الكتب العلمية، لبنان بيروت،

דبـ القرافي، أبو العباس شهاب الدين أحمد بن إدريس بن عبد الرحمن المالكي، شرح تتقيح الفصول، تحقيق: طه عبد الرؤوف سعد، شركة الطباعة الفنية

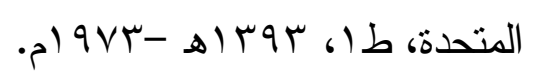

TV - القرطبي، محمد بن أحمد بن أبي بكر بن فرح أبو عبد الله، الجامع لأحكام

$$
\text { القرآن، دار احياء التراث العربي بيروت - لبنان، } 0 \text { ـ ـ اهـ. }
$$

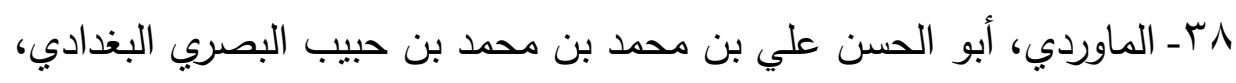

الأحكام السلطانية، دار الحديث، القاهرة.

وبـ المرداوي، علاء الدين أبي الحسن علي بن سليمان المرداوي الحنبلي،

التحبير شرح التحرير في أصول الفقه، تحقيق: د. عبد الرحمن الجبرين، د.

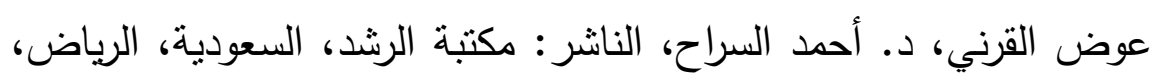

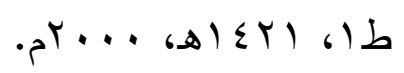

• ع - معركة الثوابت بين الإسلام والليبرالية، تأليف: د: عبد العزيز مصطفى كامل، سلسلة تصدر عن مجلة البيان، مطبوع بدون طبعة وتاريخ. 
בـ اءـ الندوة العالمية للشباب الإسلامي، الموسوعة الميسرة في الأديان والمذاهب والأحزاب المعاصرة، إثراف وتخطيط ومراجعة: د. مانع بن حماد الجني، الناشر : دار الندوة العالمية للطباعة والنشر والتوزيع، ط: ع، ـ ـ اهـ.

\section{المواقع الإلكترونية:}

r₹ ـ الانتحار في الغرب، ظاهرة تستحق التأمل، موقع لها أون لاين. https://cutt.us/vIZuN

https://cutt.us/Bmv6P -صحيفة اليوم الإلكترونية: 